\title{
المتكلم في محاضرة البابا* من هو؟
}

\section{أبو يعرب المززوقي*}

تمهيد:

لما قرأت عنوان المحاضرة1 التي ألقاها البابا في إحدى جامعات مسقط رأسه، اشتد عندي حب الاطلالع. كنت أنتظر خطاباً يجمع بين حميمية السيرة الذاتية وجدية المفكر الجامعي، الذي وصل إلى ذروة السلطة: جمعاً بين رئاسة المؤسسة الروحية، والمؤسسة السياسية الغربيتين التقليديتين. أربع صفات اجتمعت في رجل: بجديد العهد مع الجامعة (أستاذ جامعي)، والفكر (مفكر يتأمل الشأن الإنساني)، وكونه الحبر الأكبر (البابا)، ورئيس دولة (دولة الفاتيكان). وهي صفات كان يتوقع من صاحبها أن يأتي بالعجائب، وكان من المفروض أن يقدم لنا درساً نموذجياً في الموضوع الذي اختاره؛ فيقول في جوهر الإيمان والعقل ما يعالج أزمة الإنسانية، خاصة مع زعم المتكلم أنه جاعل منهما مادة للعلم، بمعناه الأكاديمي الراقي والمتحرر، بمنظور الواجب من المذهبية والانهياز اللاهوتي المقيت.

لكن ما قرأته لم يكن سيرة ذاتية تطل على الإنسانية من أبعاد المسألة الروحية، بل هي سيرة ذاتية مقصورة على مدخل للكالام على أزمة التعليم اللاهوتي الكاثوليكي في النظام الجامعي الأوروبي. لم تكن مدخلا لخطاب يوجه إلى الإنسانية لعلاج أزمتها الروحية، كما قد يوحي حدا العنوان: الإيمان والعقل، بل هي خخاطبة الإنسان الأوروبي الذي حصر في تاريخ الأديان عنده تاريخ العالم كله، وذلك من منطلق أزمة العلاقة بين

* المقصود هو بابا الفاتيكان الحالي واسمه بندكت السادس عشر.

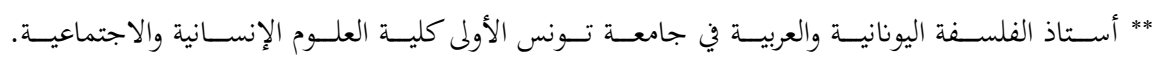
abouyaareb@yahoo.com 1 عنوان المحاضرة: الإيمان (العقيدة) والعقل والجامعة. وألقيت في الساحة الكبرى لجامعة رجنسببيرج في الثاني عشر من

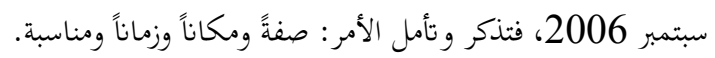




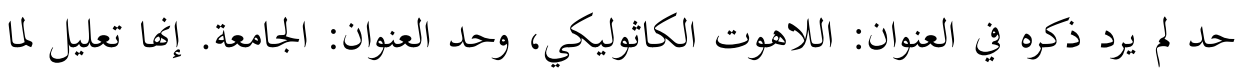

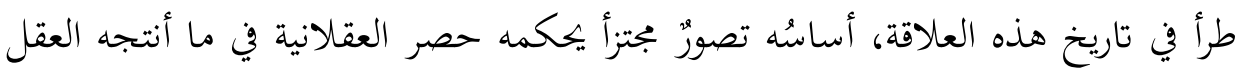

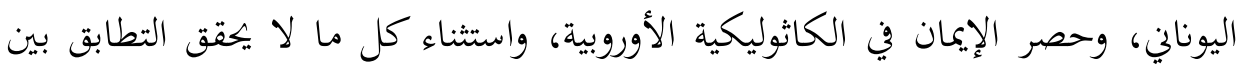

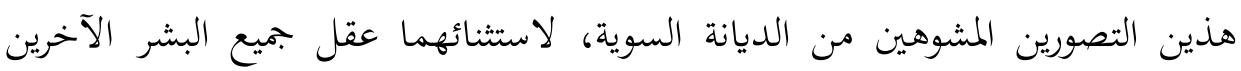

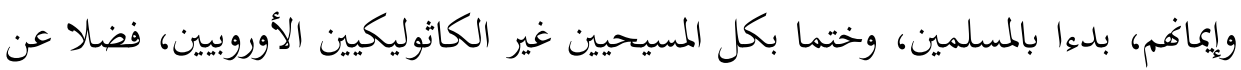

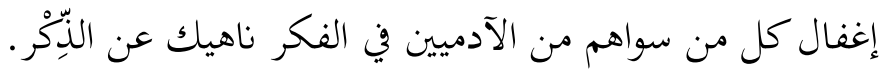

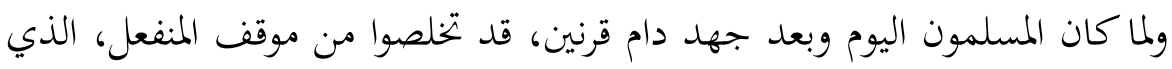

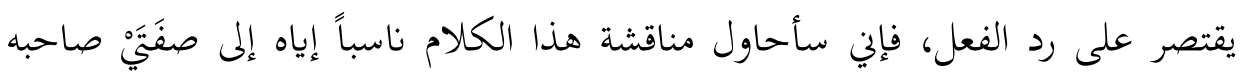

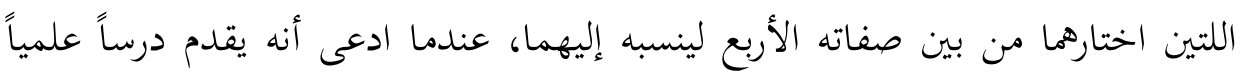

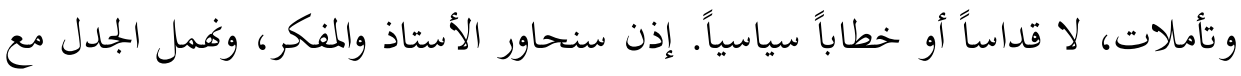
البابا ورئيس الدولة. لكننا لن نغفل الصفة الخامسة التي بقيت ضمير الدرس والتأمل.

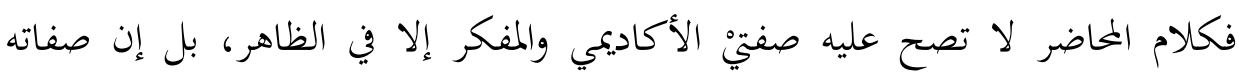

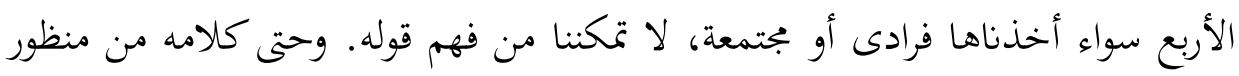

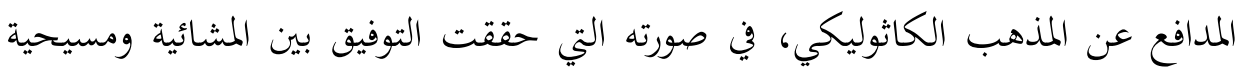
توما الإكويني، لا يكفي للفهم.

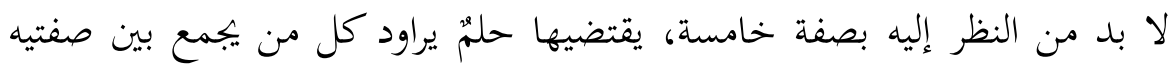

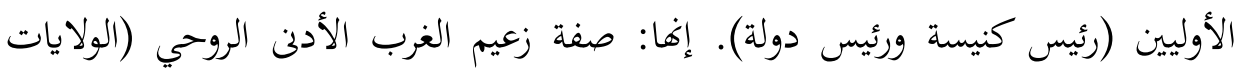

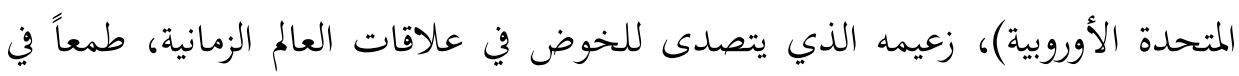

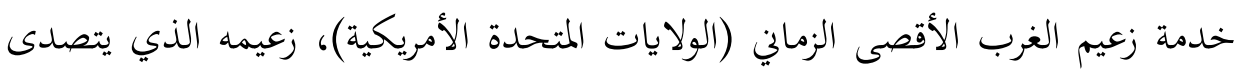

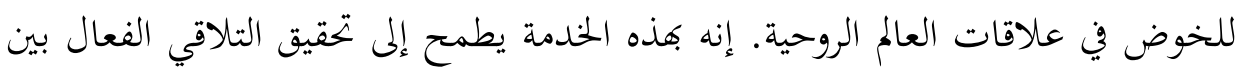

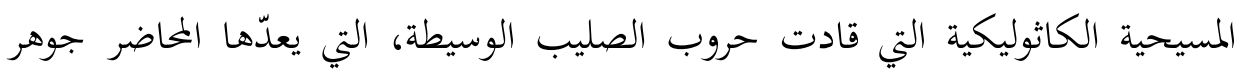

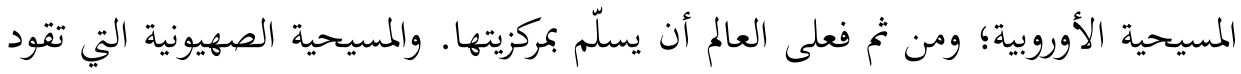

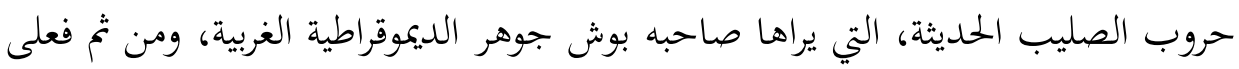


العالم أن يسلّم بمركيتها. وكل ذلك غني عن الدليل: تكفي القرينة الزمانية، ومماهاة البابا

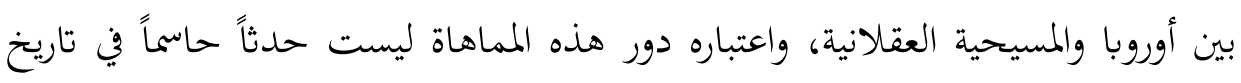

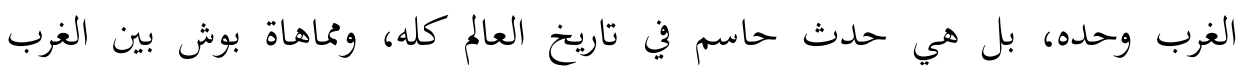

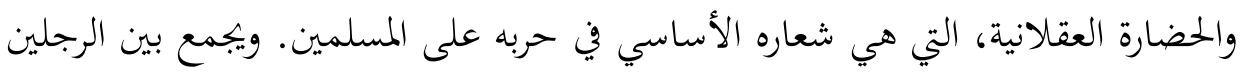

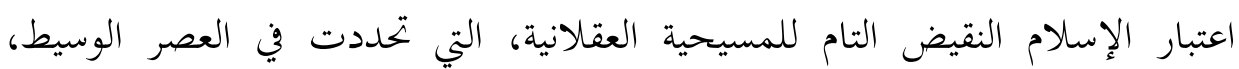

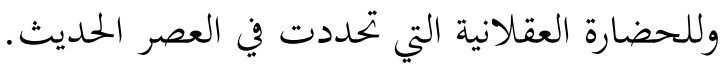

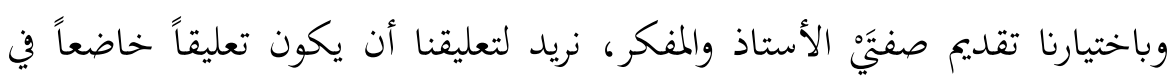

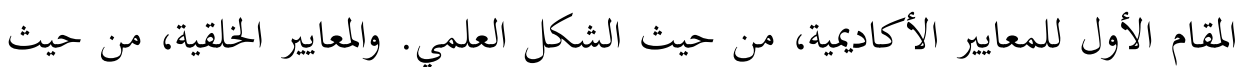

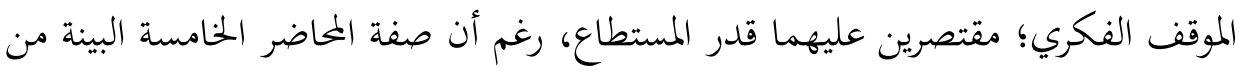

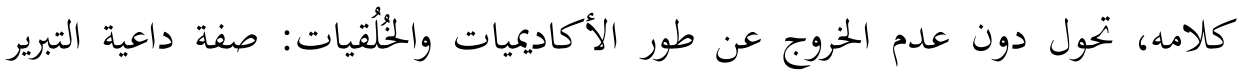

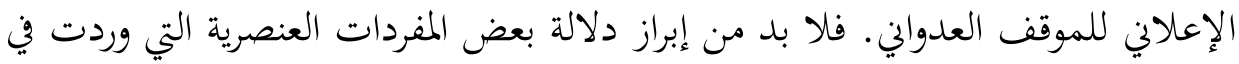

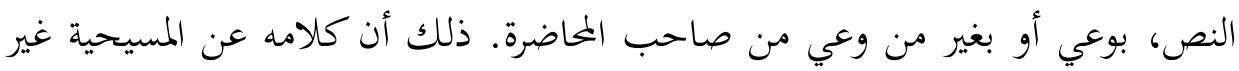

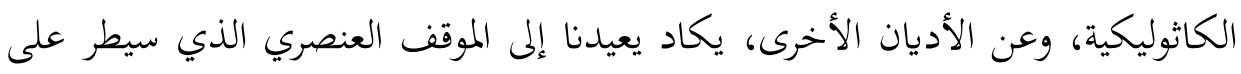

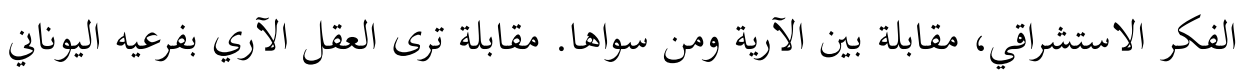

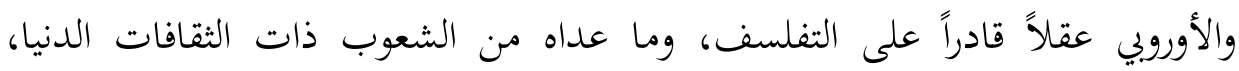
شعوب بدائية لا عقل ها ولا قدرة على التفكير. وسوف تتضمن عناصر هذه الورقة: بيان خطة المحاضرة ومنطقها، ومناقشة أخطاء المحاضر الشكلية، ثم مناقشة أخطائل أخدائه

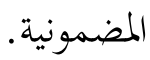

\section{المسألة الأولى: خطة الخحاضرة الصريحة ومنطقها}

ولنبدأ بأيسر الأمور، فنحدد الخطة التي اتعها المحاضر في علاج مشكلة العلاقة بين

2 تاريخ الحاضرة هو يوم 12 سبتمبر، وعلاقته بـ 11 سبتمبر على الأقل بالجوار المباشر علاقة بليغة. 
الإيمان والعقل والجامعة، بمنظور وَصَفَه صاحبُ المحاضرة في شبه عنوان بكونه تذكراً

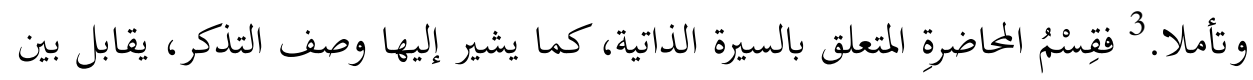

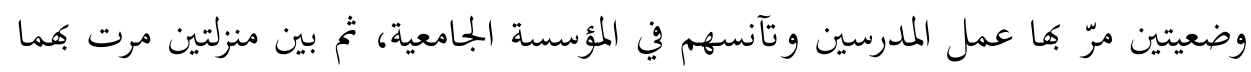

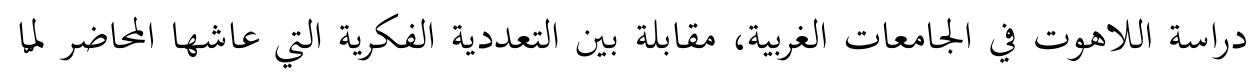

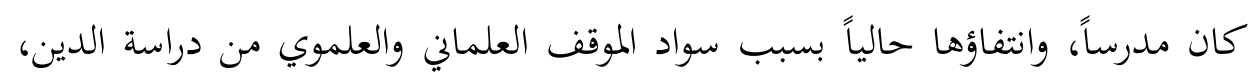
بديلا من دراسته اللاهوتية في الجامعات.

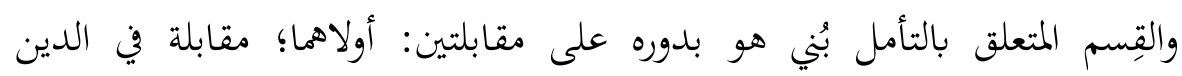

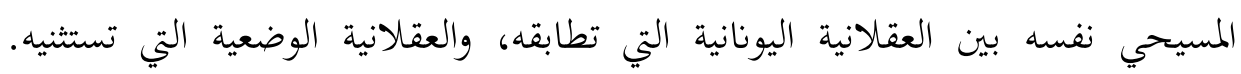

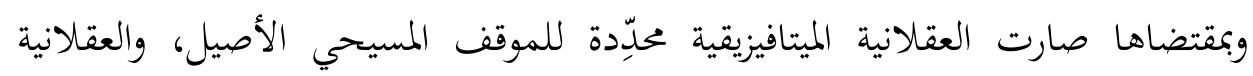

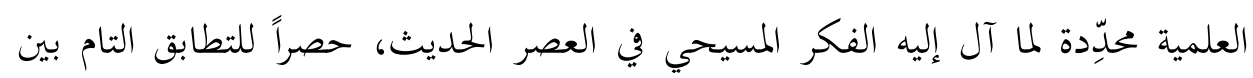

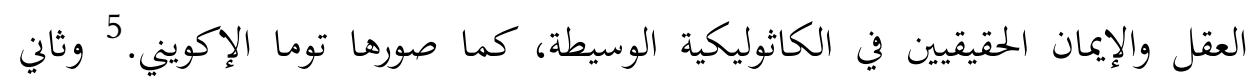

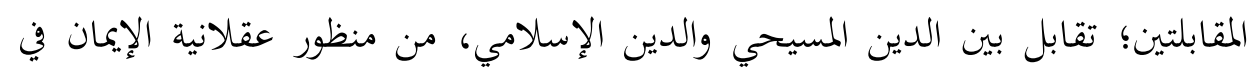

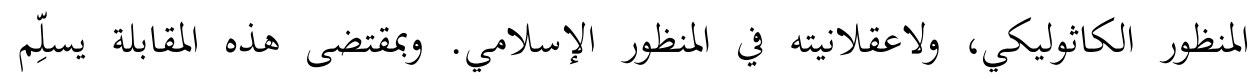

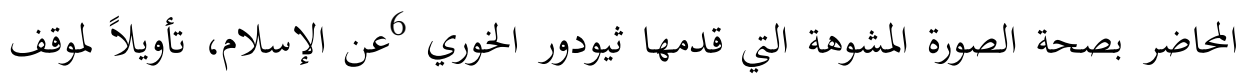

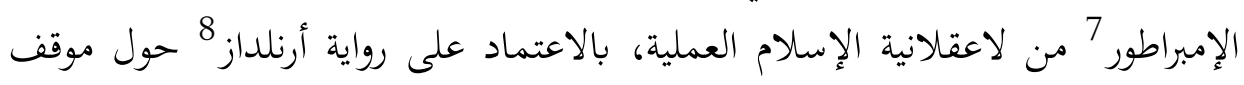

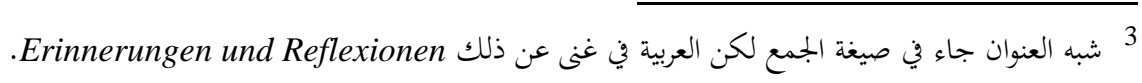

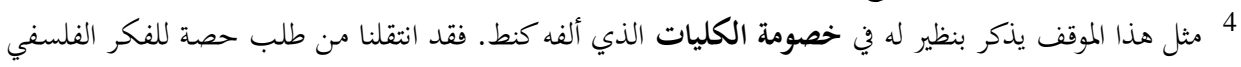

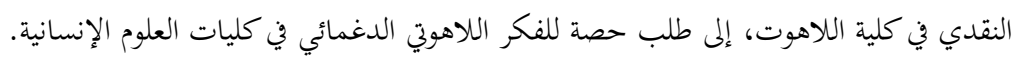

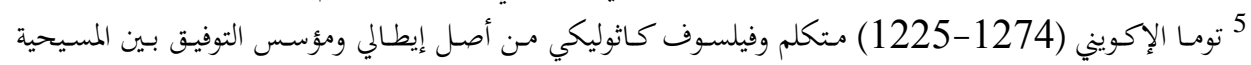

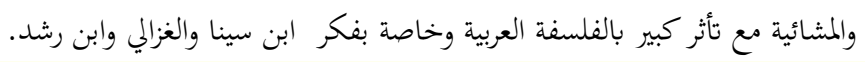

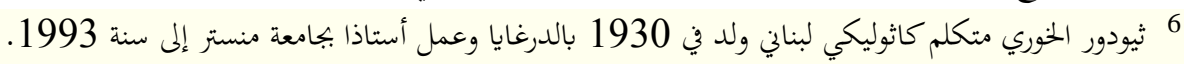

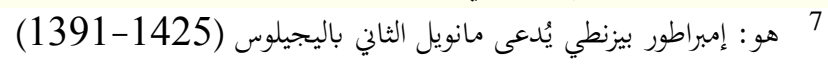

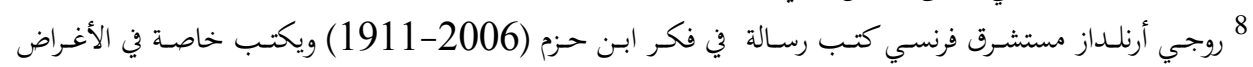


ابن حزم الممثل للاعقلانية الإسلام النظرية.9 9

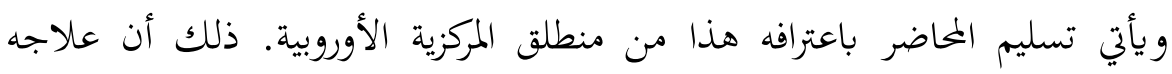
مسألة العلاقة بين الإيمان والعقل في الجامعة، قد استند صراحة إلى أنس مسأل مألة العلاقة بين الإيمان والعقل، كما تعينت في هذه المقابلة بين العقلانية الكاثوليكية، واللاعقلانية

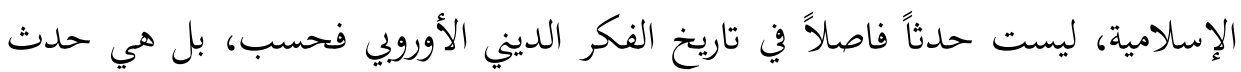
فاصل في تاريخ العالم. فهو يرى أن الكاثوليكية في صورتا الأوروبية الوسيطة هي التي

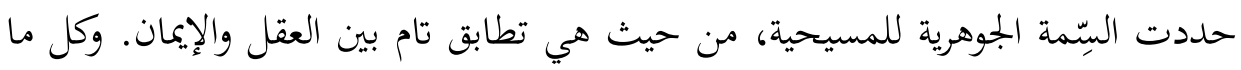

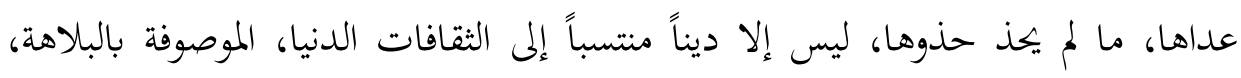
وفقدان القدرة على التعقل.

تلك هي العلاقة، التي جعلت المحاضر يتخذ المناظرة التي رواها الخوري منطلق تأملاته. 10 فآراء ثيودور الخوري التي يزعم بفضلها تفسير موقف الإمبراطور المحاصر من

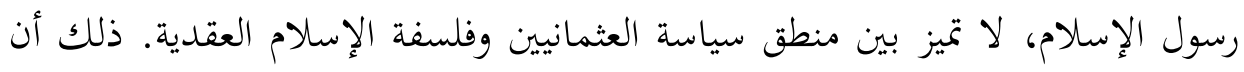
الهدف ليس فهم الموقف بأسبابه الحقيقية، بل تبرير الصورة التي تشوه مفهوم الجهاد

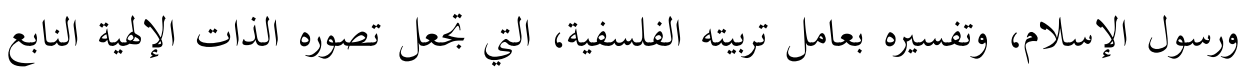

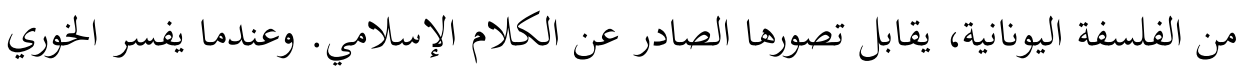
رأي الإمبراطور بالمقابلة بين موقف من رُبّي على تقاليد الفلسفة اليونانية في تصور الله الله

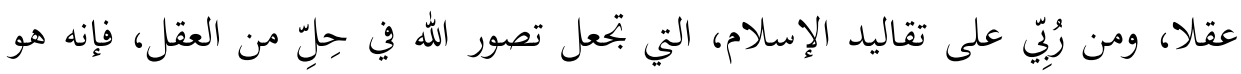

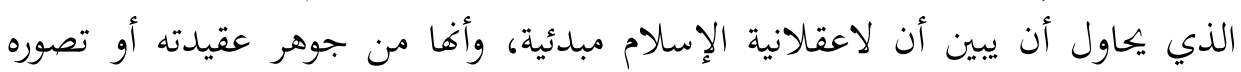

9 من الإنصاف القول إن المحاضر ليس هو نفسه صاحب الصورة المشوهة بل ثيودور الخوري. واكتفى المحاضر بتبني موقفه

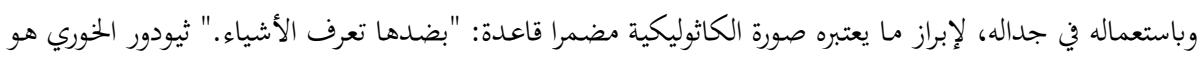

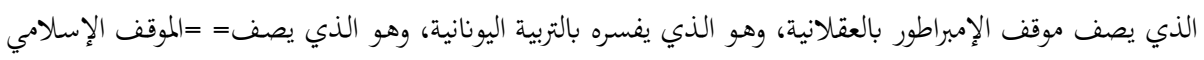

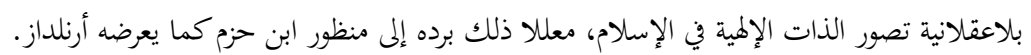

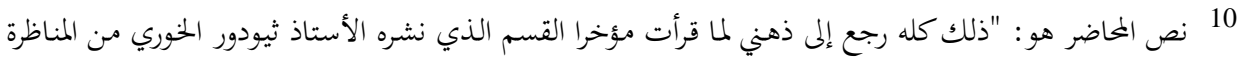

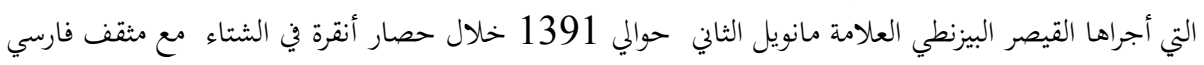




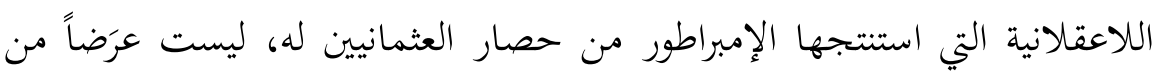

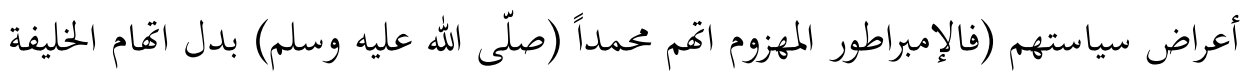

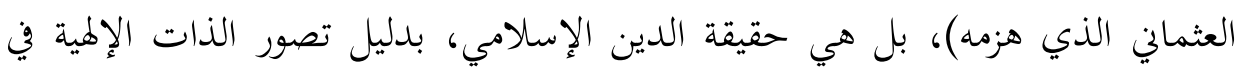

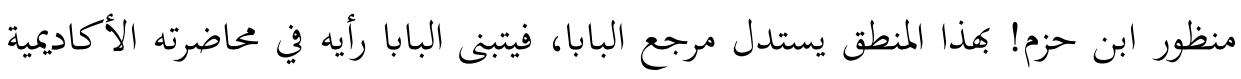

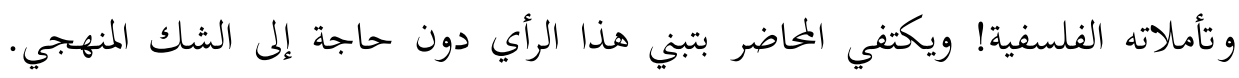

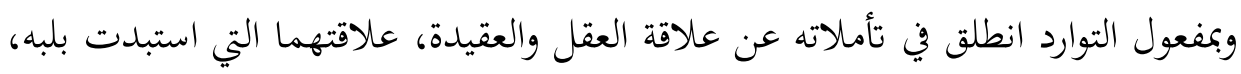

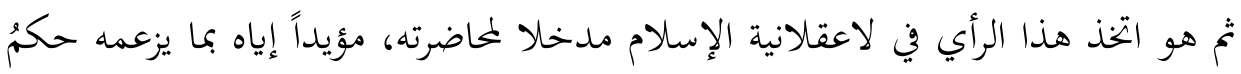

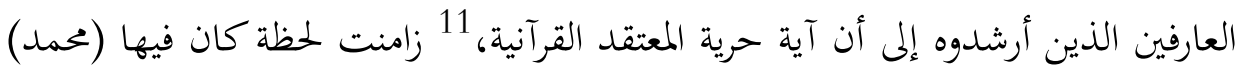

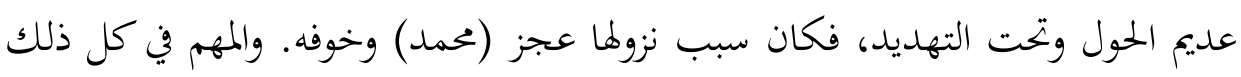

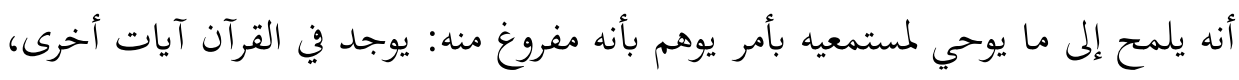

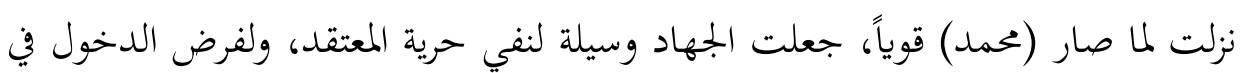

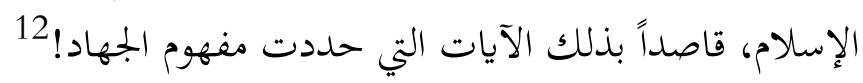

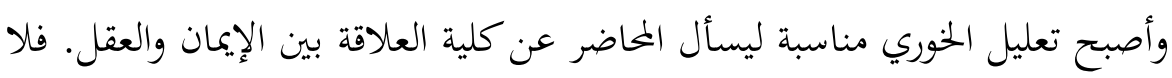

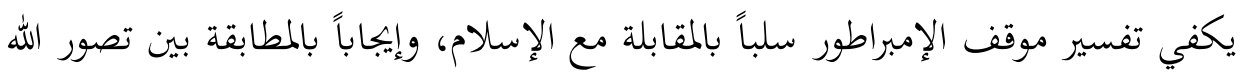

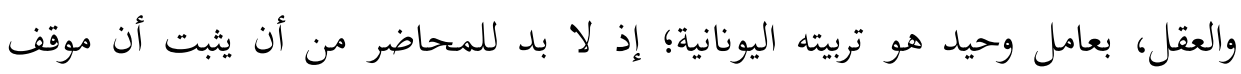

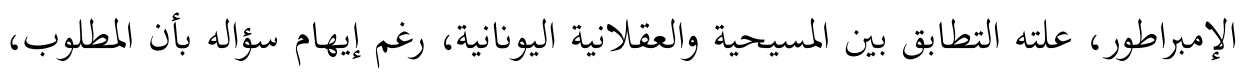

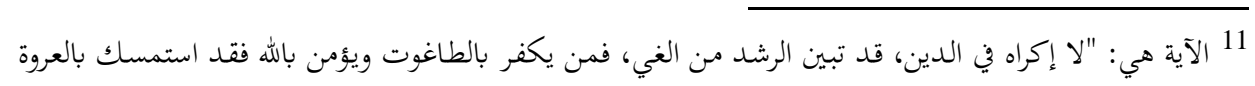

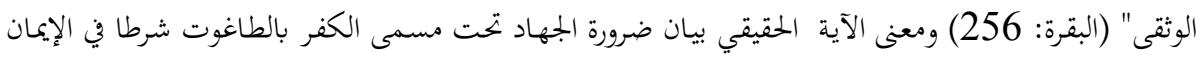
الحق بالله.

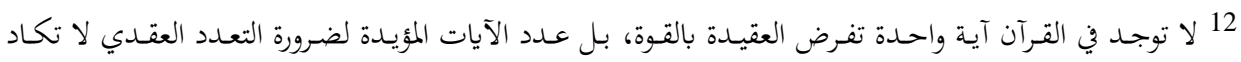

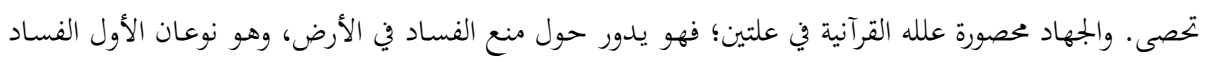

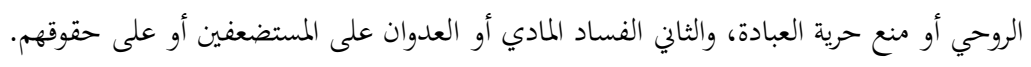


هو بيان كلية القاعدة التي ترى الله يفعل بمقتضى العقل 13 لـذلك فموقف الإمبراطور من

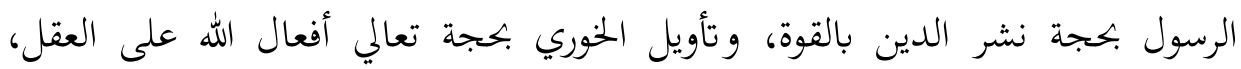

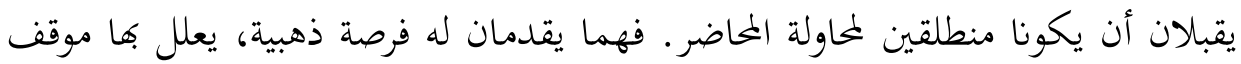
الإمبراطور وموقفه الشخصي في الدعوة للحوار من نفس منطلق الإمبراطور، ليحرر

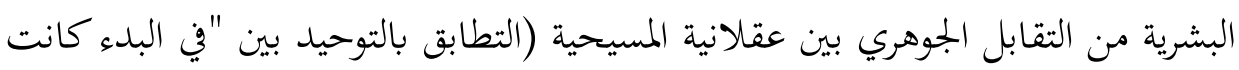

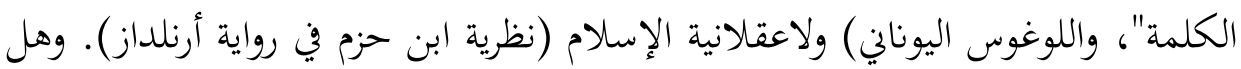

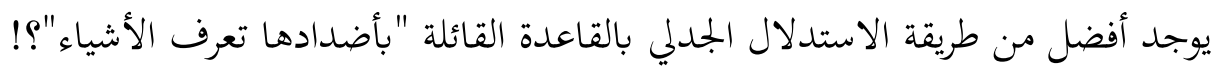
وإذن، فالمحاضر يبدو بريئا من صنع الصورة المشوهة؛ إذ اكتفى باستعمال الموجود،

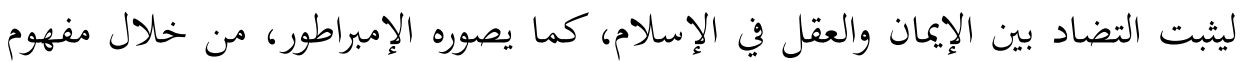

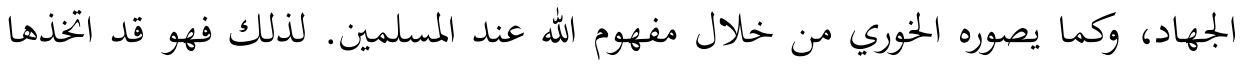
بداية وغاية لمحاضرته كما أسلفنا. أليست هذه مُهورة طريقة جيدة لمن يمارس التبشير بدل التفكير، ما دامت تمده بتعريف ملموس لضدي التصور المسيحي العقلاين، على الأقل في

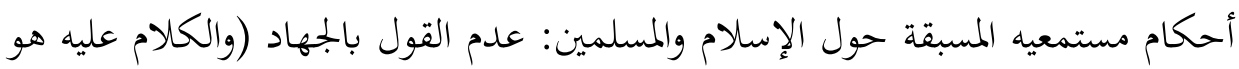

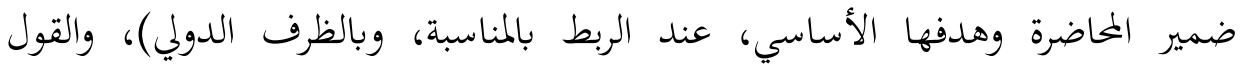
بعقلانية الفعل الإلهي للتطابق بين النظرية الكاثوليكية والعقلانية اليونانية (والكام علام عليه

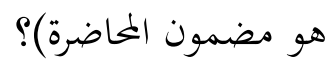

وعندئذ يأتي ما يقدمه المحاضر على أنه بيت القصيد في تأملاته: دراسة العلاقة بين الإيمان والعقل في المسيحية، كما يتصورها، وليصلح منزلة اللاهوت في الجامعة الغربية.

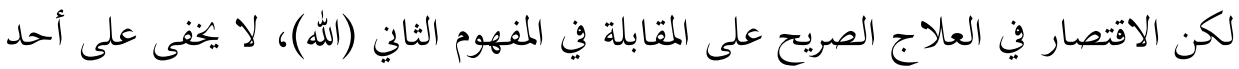
أن العلاج المضمر في المحاضرة، يدور حول المقابلة في المفهوم الأول (الجهاد)، التي أوردها الإمبراطور المحاصر، للتدليل على لا معقولية العمل الإسلامي في هاية العصر الوسيط،

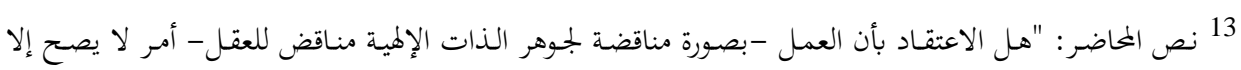

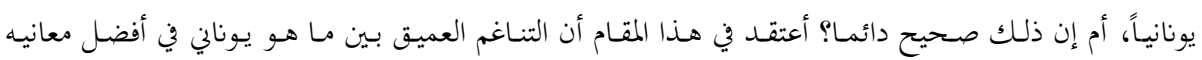

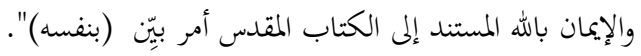


ويضربها البابا المحاضر مثالاً على تدني الثقافة الإسلامية في فاية العصر الحديث. فمفاد هذا الضمير أن المسيحية هي دين المحبة والسلام، وأفا، على نقيض الإسلام،

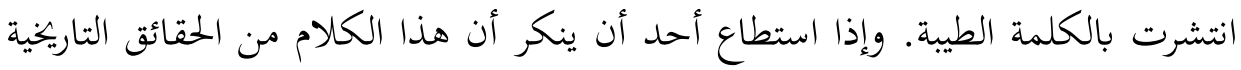

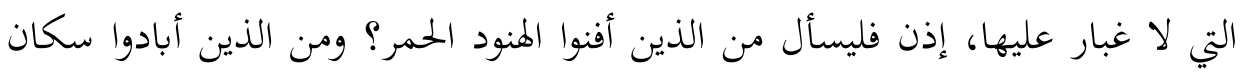

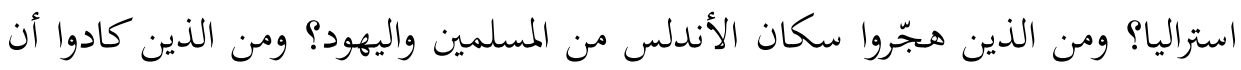

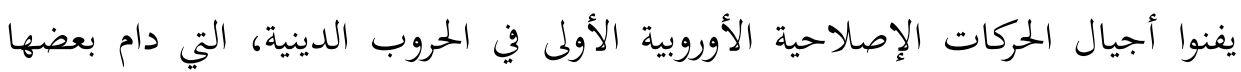
مئات السنين؟ تمح ليسأل كذلك، من الذين قادوا الحمالات الاستعمارية الغازية في إفريقيا

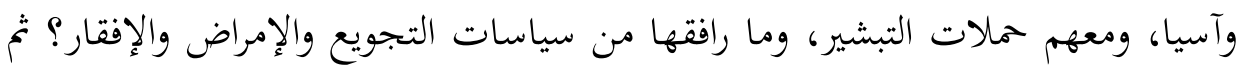

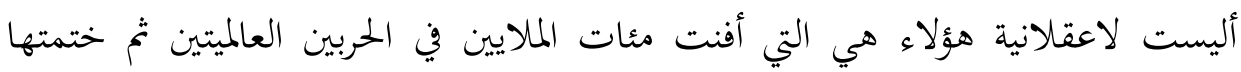

برمي قنبلتين ذريتين؟

لذلك حق للمحاضر أن يرى أنّ المقابلة بين نفي الإسلام لعلاقة الإيمان بالعقل،

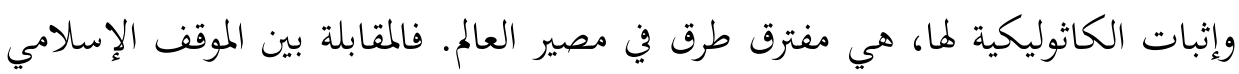

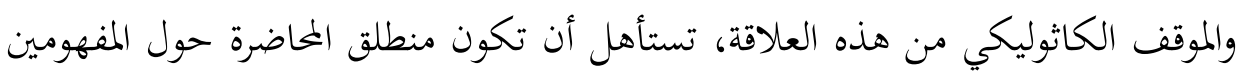

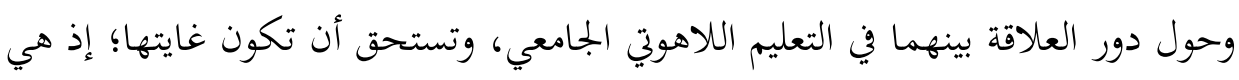
تعد عنده من أهم نتائج المحاضرة الختامية. 14

بذلك، وبذلك فقط، نفهم أن يدور تدبير المحاضرة كله على المقابلة بين الإسلام

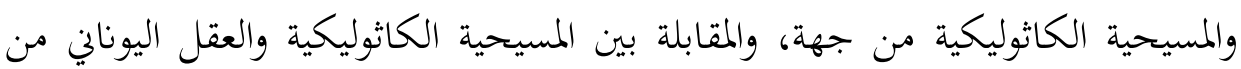

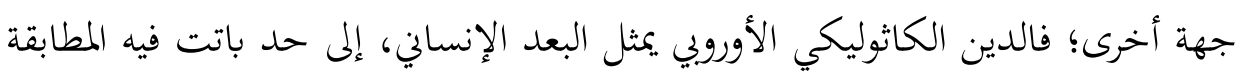

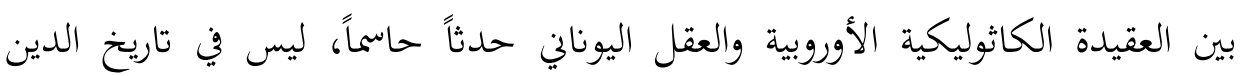

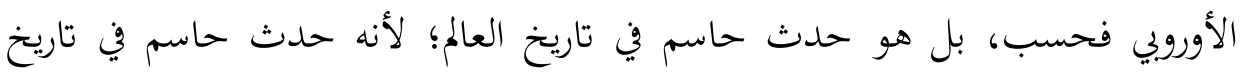

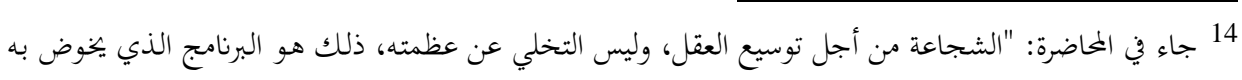

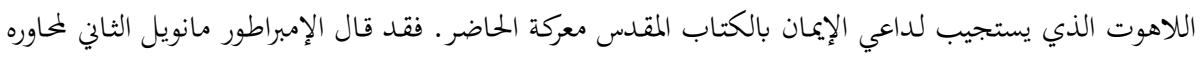

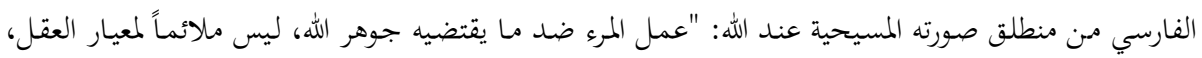
وليس عملاً ملائماً للوغوس. من صورته 
الغرب، 15 الذي تتعين فيه المعقولية الفلسفية والدينية. 16 وهكذا تتوالى مسائل المحاضرة بصورة شبه منطقية. فتعليل بداية المحاضرة وغايتها هو الذي يفسر توالي قضاياها، ويعلل علاقتها بالإسلام، وبنكوص حوار الأديان عند المحاضر إلى حوار الثقافات، وكذلك في سياسة الفاتيكان منذ أن تولى رئاسته بندكت السادس عشر؛ فكل الأديان الأخرى ليست، عند المحاضر، أدياناً، إنما هي ثقافات فحسب، بل هي من ججال الثقافات الدنيا. ومنطق المحاضرة يقتضي أن يثبت المحاضر لاعقلانية الإسالام في مستوييها العملي والنظري، حتى يبرز المقصود بعقلانية الكاثوليكية. فالإسلام لم يأت عملياً إلا بالشرور، وأهمها فرض العقيدة بالقوة (نظرية الجهاد في مقابل عرض الحند الثاني الصليبي الوسيط والحديث وأهم صفاته المجبة والسالام النووي!) كما حكم الإمبراطور. والإسلام لم يأت نظرياً إلا بتبرير الشرور، لاعتباره إرادة الله تحكماً مطلقاً، لا يكتفي بمخالفة العقل فحسب، بل هو يخالف ذاته كذلك؛ إذ يمكنه ألا يهترم وعده إلى حد القدرة على جعل الإنسان يشرك به لو أراد، كما فهم أرنلداز من فكر ابن حزم، واستدل بعرضه ثيودور الخوري، لإفهامنا الفرق بين الإمبراطور العقالني وحاوره المسلم التحكماني. ولا بد من إثبات العقلانية الكاتوليكية بججج نصية (إنجيل يوحنا)، وتحليلات تأويلية 15 وتلك هي تقريبا نغمة المركزية الغربية نفسها التي يتغنى بها هيدجر عند كلامه على تاريخ العقل الفلسفي، بوصفه

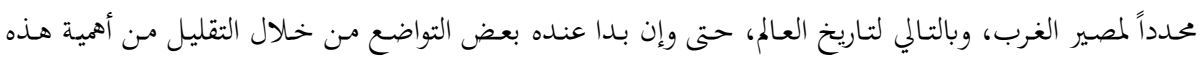

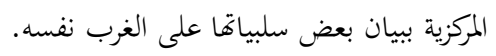

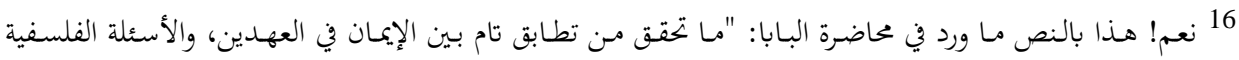

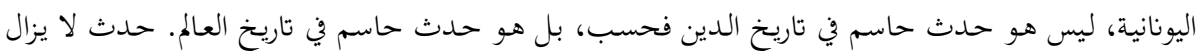

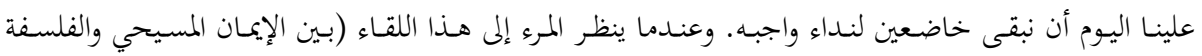

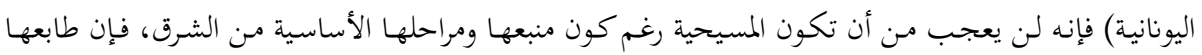

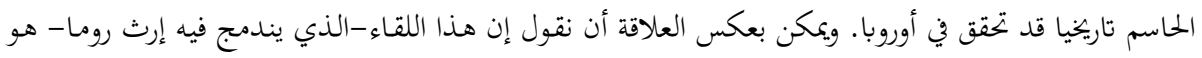

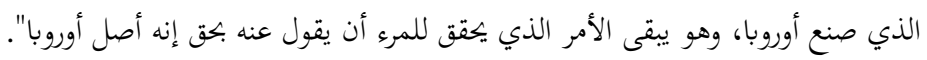

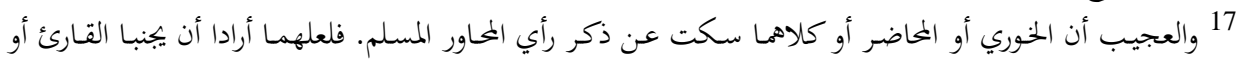


للأحلام والقصص (حلم بولس)، ونظريات كلامية (اغسطينوس وتوما الإكويني)، حتى

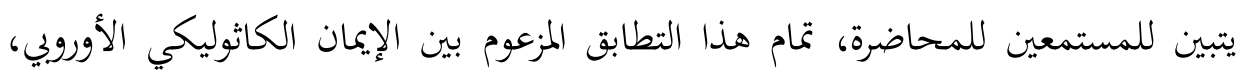

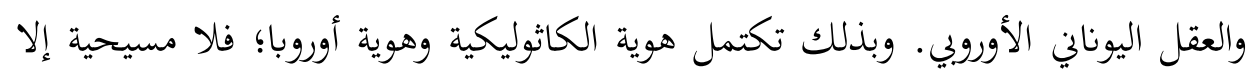

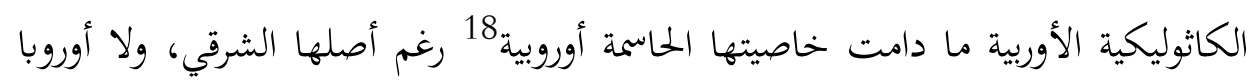

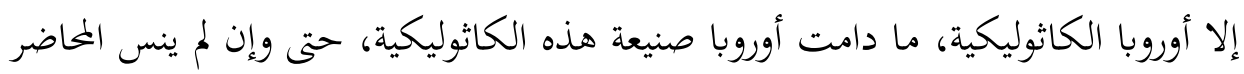

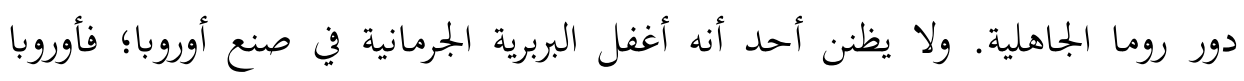

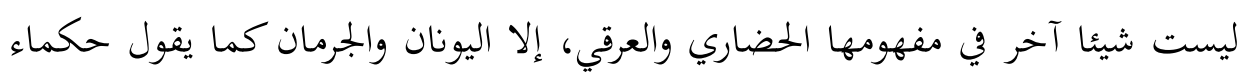

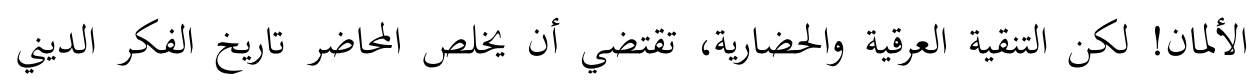

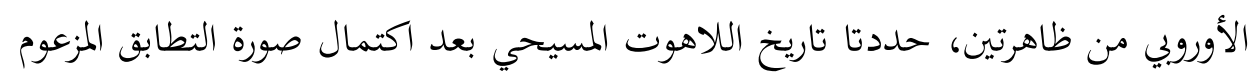
هذه بين اللاهوت الكاثوليكي والفلسفة اليونانية.

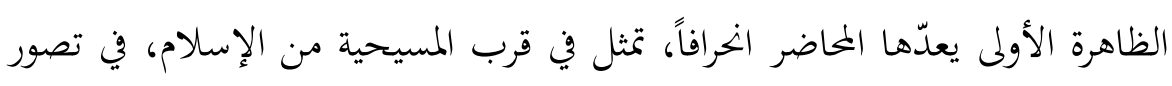

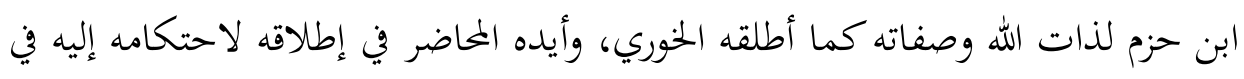

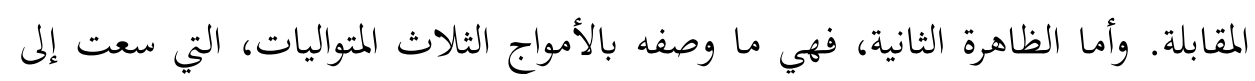

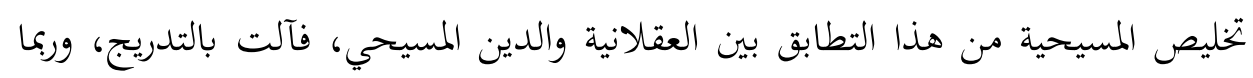

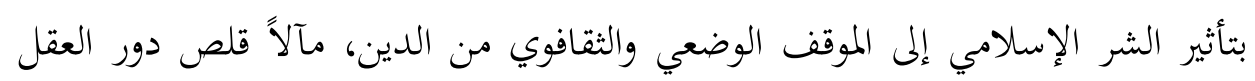
اليونائ فأخرج اللاهوت الكاثوليكي من الجامعة.

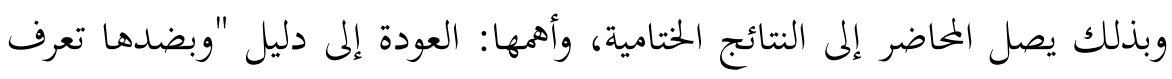

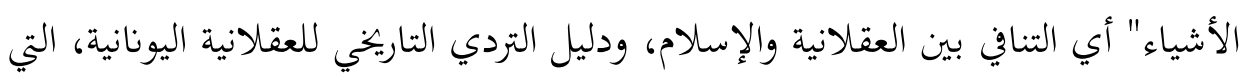

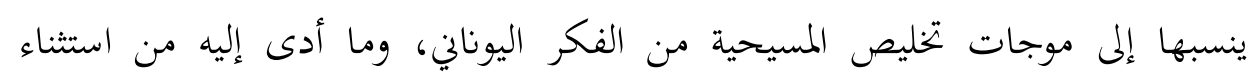

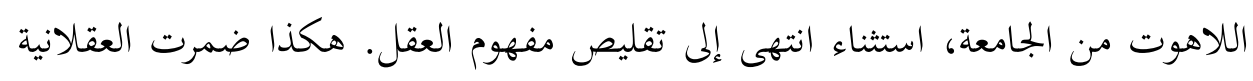

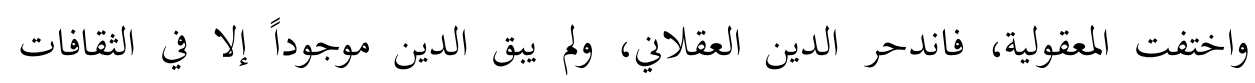

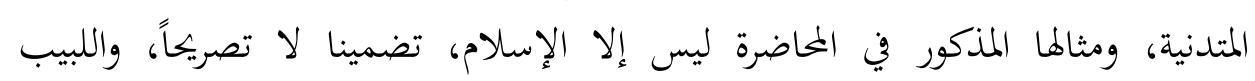

18 يقول الخاضر: "فرغم أن أصل المسيحية ومراحل تطورها المهمة قد حدثت في الشرق فإن طابعها التاريخي الجوهري قد حصل في أوروبا..." 


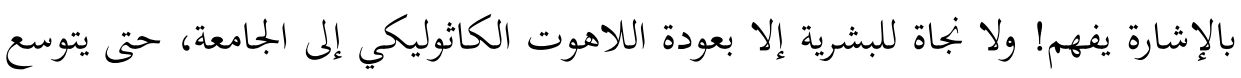

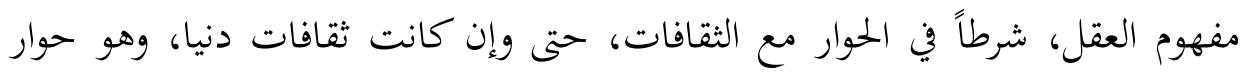
ثقافات لا حوار أديان؛ إذ لا دين إلا الكاثوليكية!

تلك هي خطة المحاضرة ومراحلها فكيف يمكن النفاذ إلى عمارتا لاستباط تدبيرها

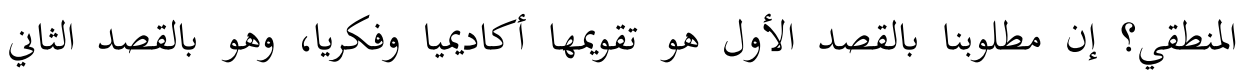

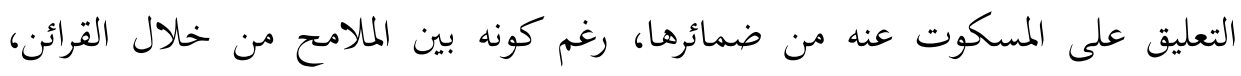

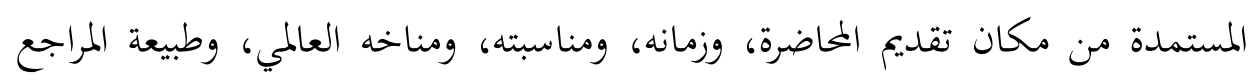
المستعملة في حججه النصية.

\section{المسألة الثانية: تعليقات على أخطاء نتجت عن الحخل الشكلي}

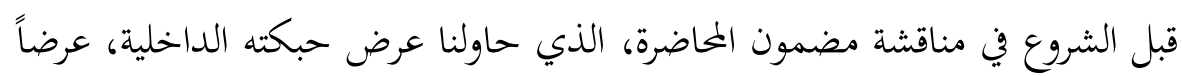

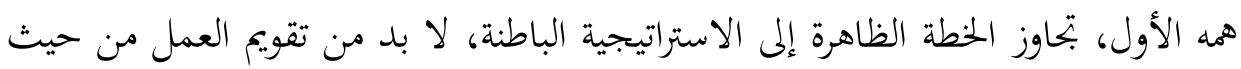

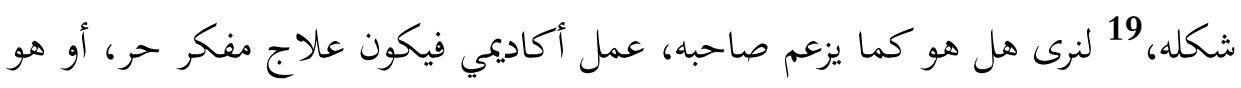

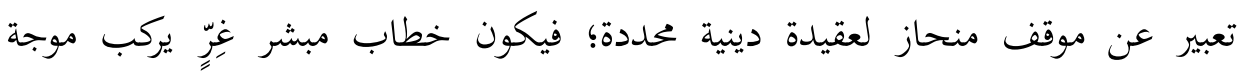

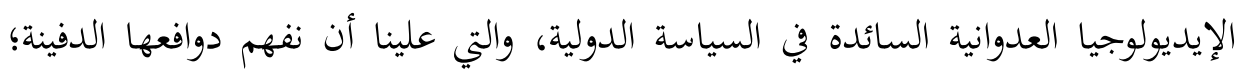

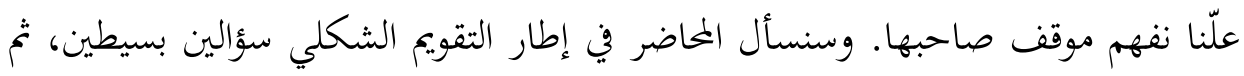

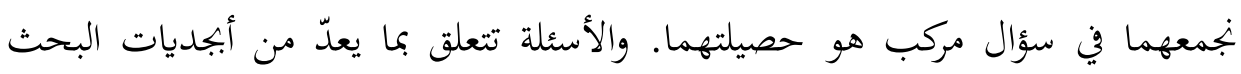
العلمي الذي يبقى المعيار الأول والأخير في تقويم المحاضرات الجامعية.

19 الملاحظة الواردة في ذيل المحاضرة في نشرها الرسمية Copyright 2006 -Libreria Editrice Vaticana كما

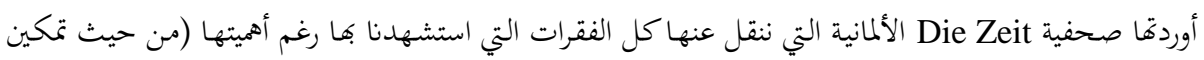

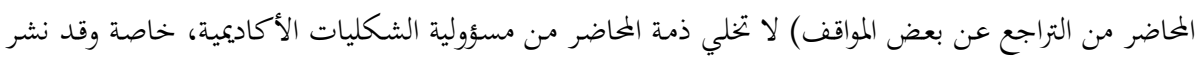

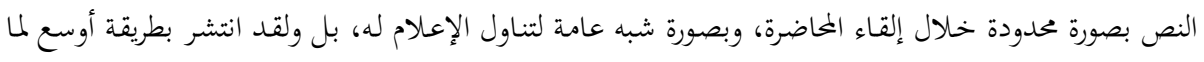

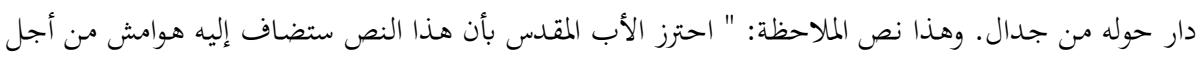
النشر. لذلك فالصياغة الحالية ينبغي أن ينظر إليها بوصفها صنا صياغة مؤقتة. 


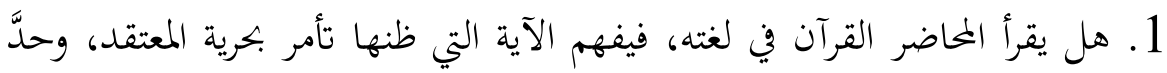

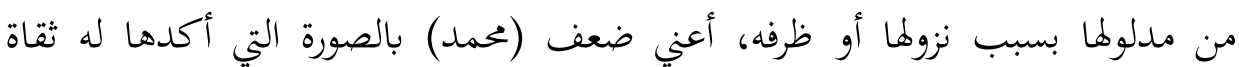
العلماء؟

2. وهل هو متأكد من العنعنة في رواية ثيودور الخوري الذي استشهد بأرنداز في تحديد نظرية الله الإسلامية، فيطمئن لعلمهما، وينبني عليه دليل "بضدها تعرف الأشياء

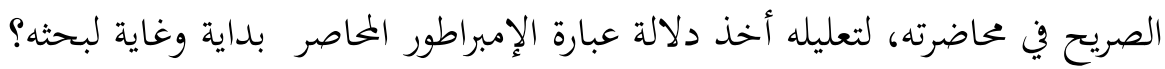

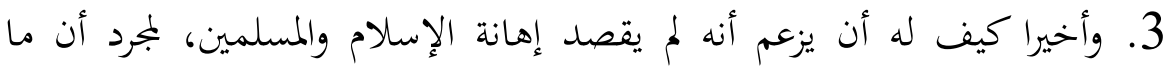

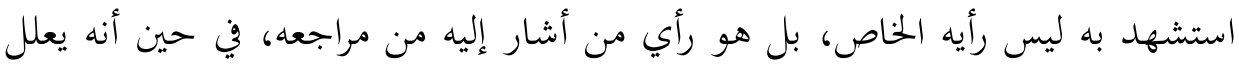

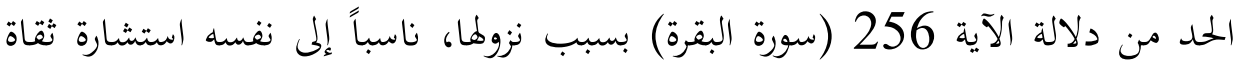

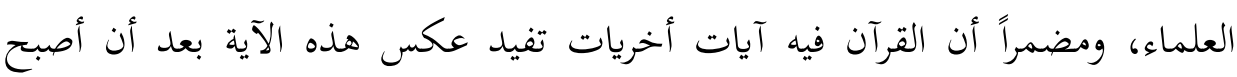

$$
\text { (محمد) ذا حول وطول؟ السؤال الأول: }
$$

لست أشك في أن المحاضر يبهل العربية. فهو قد تصور الآية 256 من البقرة

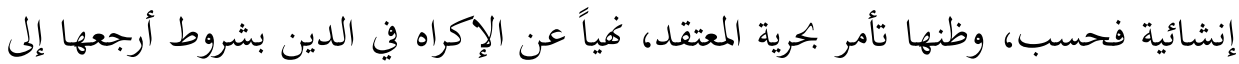

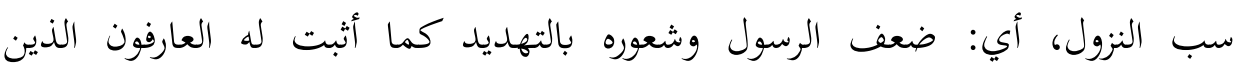

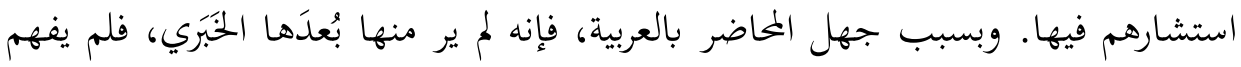

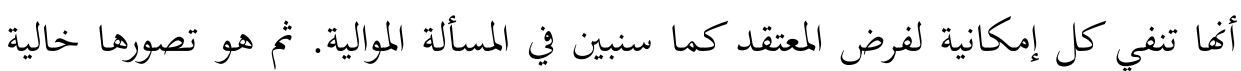

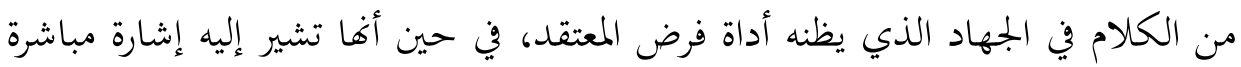

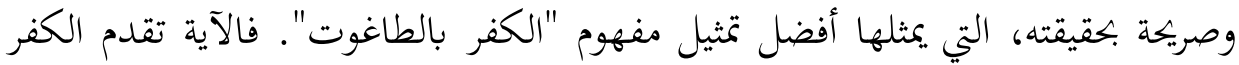
بالطاغوت على الإيمان باللة؛ لأنه هو الدال عليه، للدلالة على صدقه، والموصل إليه

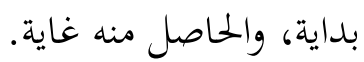
فلا معنى للكالام على سبب نزول الآية للتقليل من دلالتها الكلية، كما يزعم المحاضر 


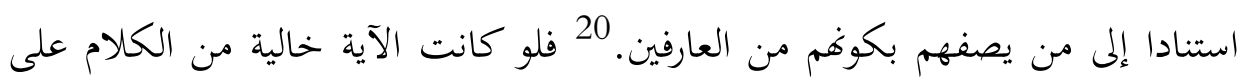

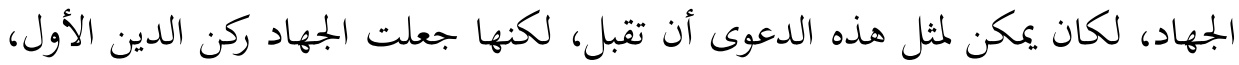

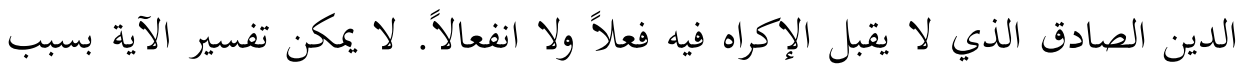

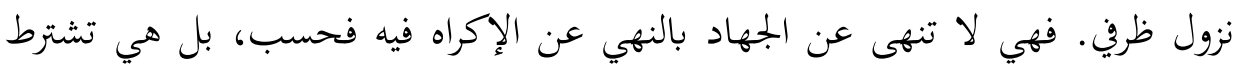

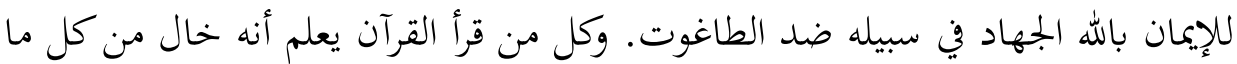

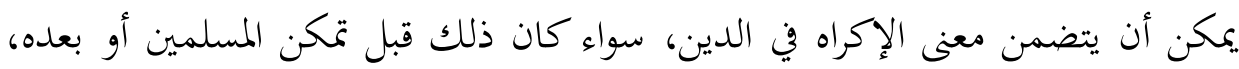

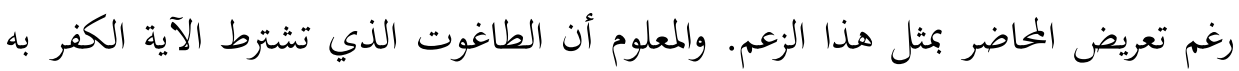

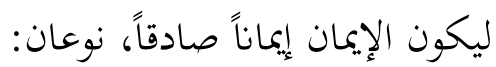

أحدهما تمثله السلطة الروحية الوسيطة بين الإنسان ورزقه الروحي. وذلك هو

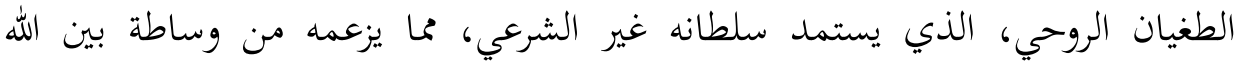

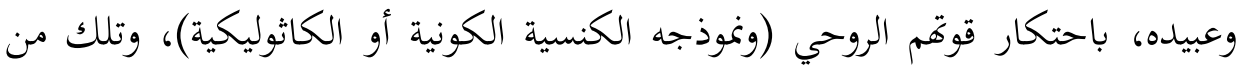
العلل الرئيسية لمناصبة الكنائس العداء للإسلام في كل العصور . والثاني تمثله السلطة الزمانية الوسيطة بين الإنسان ورزقه المادي. وذلك هو الطغيان المادي، الذي يستمد سلطانه غير الشرعي، مما يزعمه من وساطة بين الله وعبيده

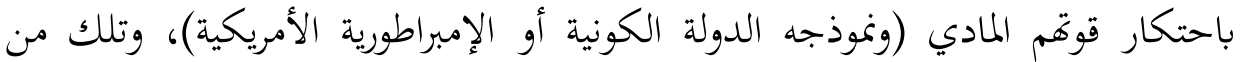
العلل الرئيسية لمناصبة الإمبراطوريات العداء للإسلام في كل العصور. وليس من شك في أن ذروة الطاغوت المطلق هو التحالف بين الطاغوتين، وعلامته

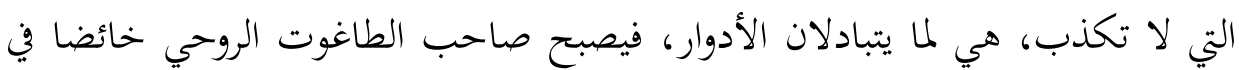

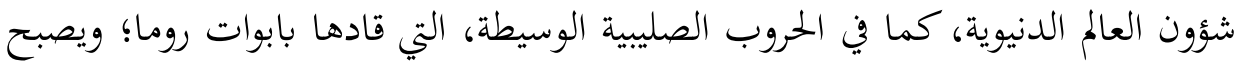

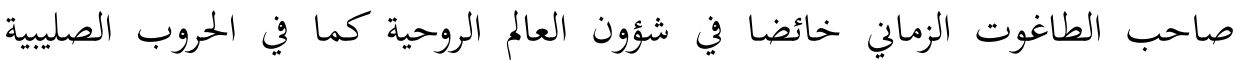

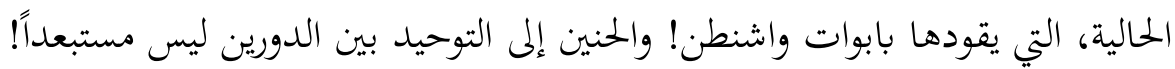

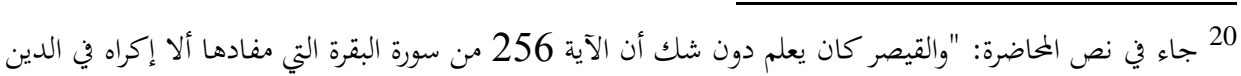
هي من السور الأولى من عهد كان فيه محمد ذاته فاقدا للقوة وتحت التهديد كما قال فال لنا لنا العارفون." 
لذلك فآية حرية المعتقد لم تختم بصفتين من صفات الله مناسبتين لمضمون الآية

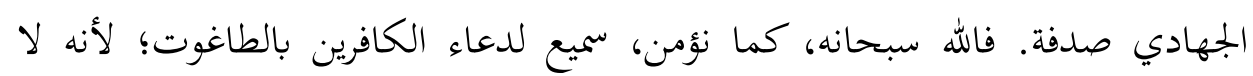

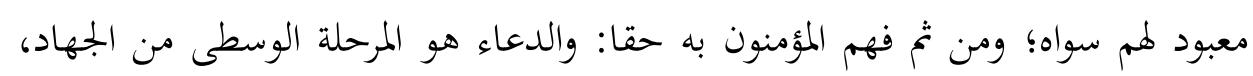

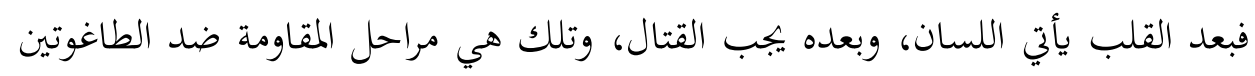

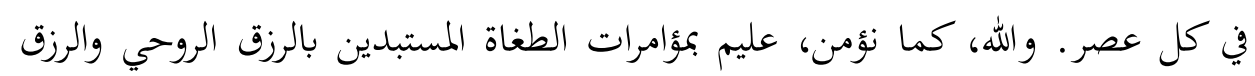

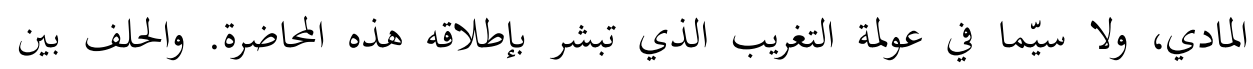
الطاغوتين قاعدة عامة. السؤال الثاني:

اعتمد محاضرنا الأكاديمي على عنعنة لم تعد في عصرنا مقبولة، بل كانت دائما

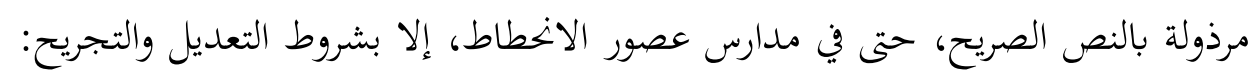

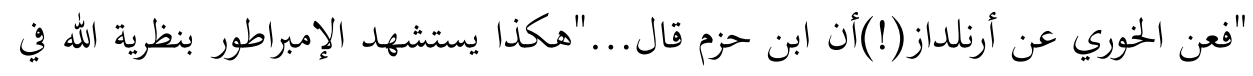

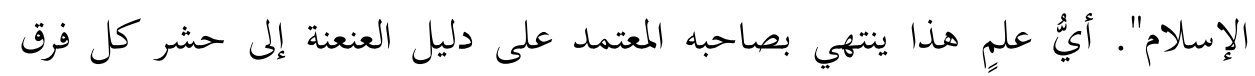

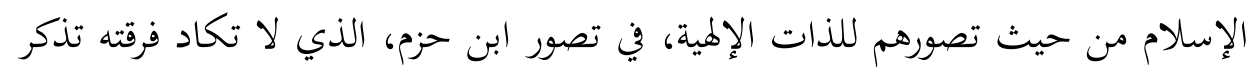

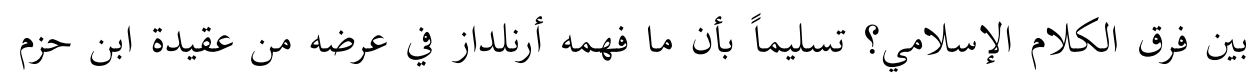

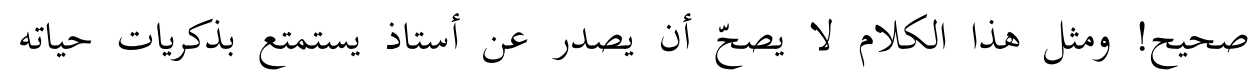

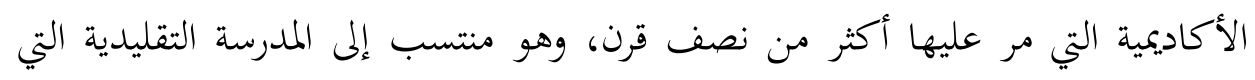

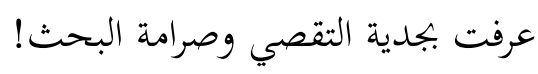
وكم هو مضحك أن يتكلم المحاضر على ما أوجبته عليه "النزاهة الفكرية"! حينما

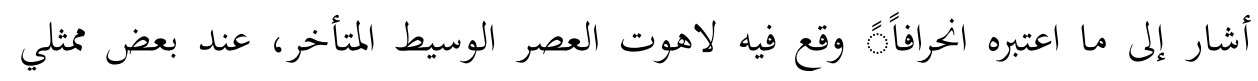

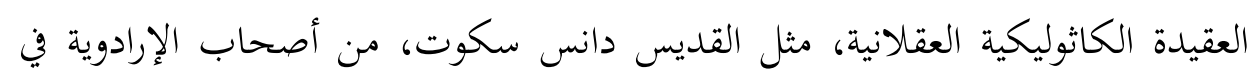

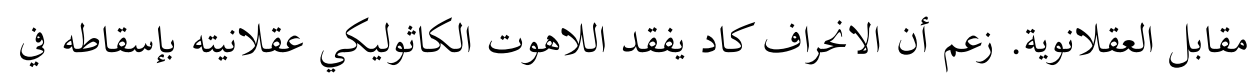

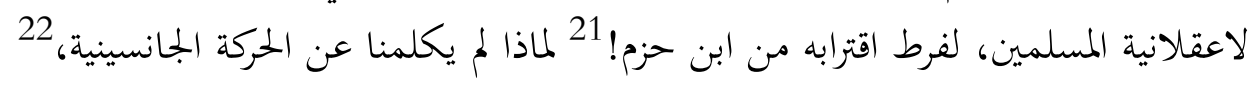

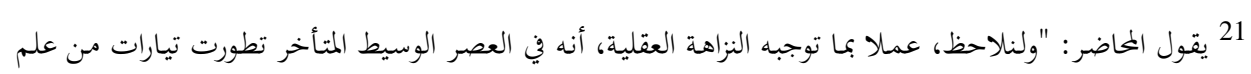

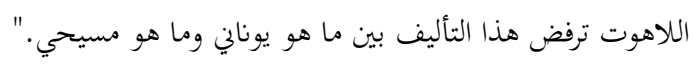


وعن ديكارت، 23 وباسكال، ${ }^{2}$ وكل الذين كانوا يرون أن قدرة الله وإرادته هما صفتاه

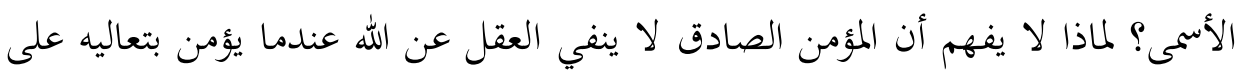

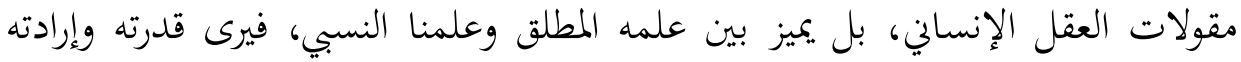

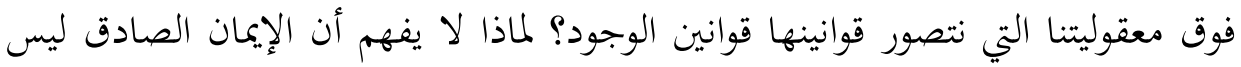

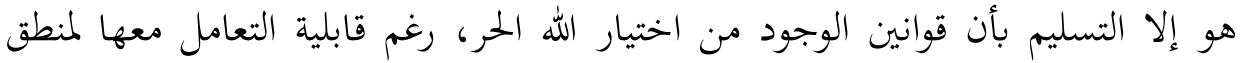

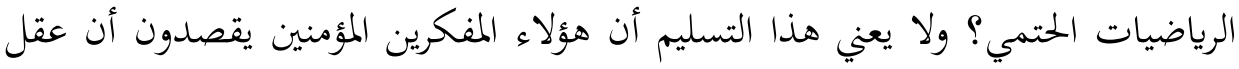

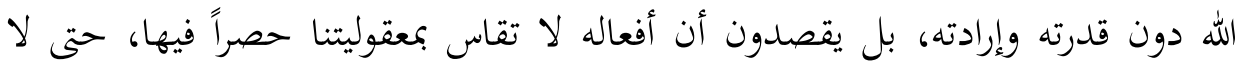

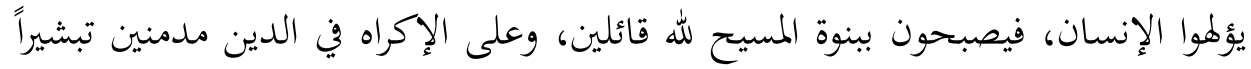

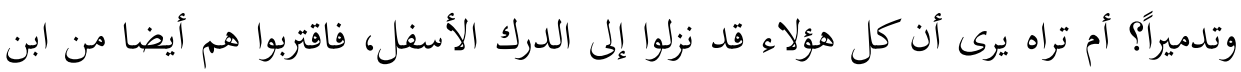

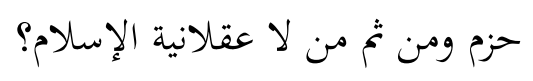

ليت المحاضر يستطيع إفهامنا، بعقلانيته اليونانية الصارمة! أسرار الكاثوليكية

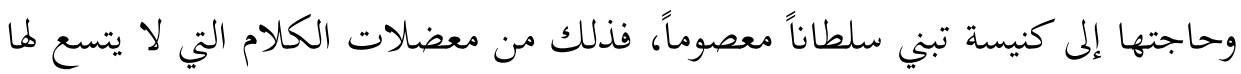
محل هذا البحث. وليته يبيّن لنا مدى العقلانية في قرارات تلغي الفطرة الإنسانية في الفي لئي

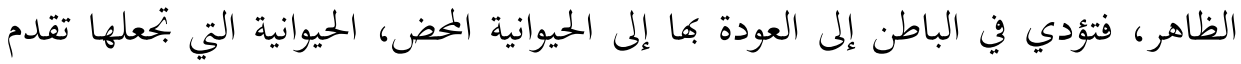

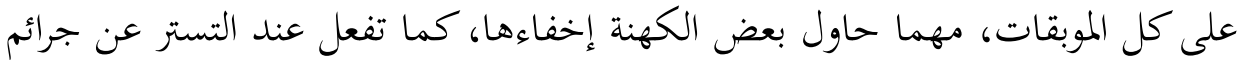

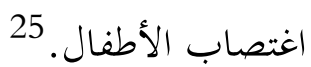

كيف لمحاضر ومفكر أن يعتمد على العنعنة من دون العودة إلى المصادر نفسها؟ ما الذي حال دونه والسؤال- في اعتماده على هذه العنعنة التي تلتقي بمصدريها (الامبراطور

22 حركة إحيائية للمسيحية الكاثوليكية في صيغتها التي أعطاها إياها القديس اغسطينوس، أسسها كورنيليوس جنسون

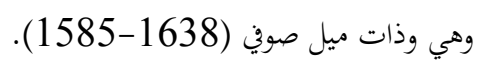

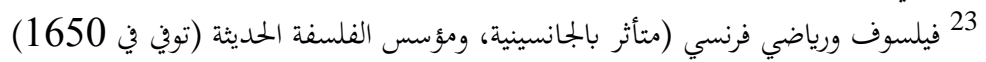

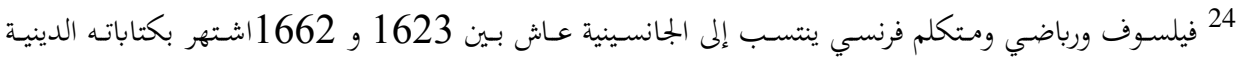

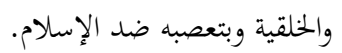

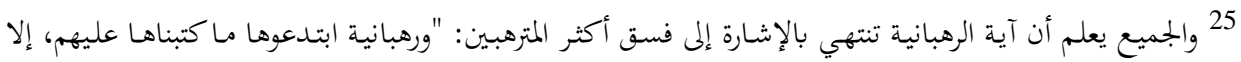

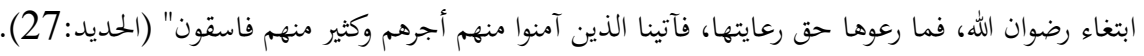


في نظرية الجهاد، وأرنلداز في نظرية الله الإسلاميتين) عند الخوري- عن مدى صحة

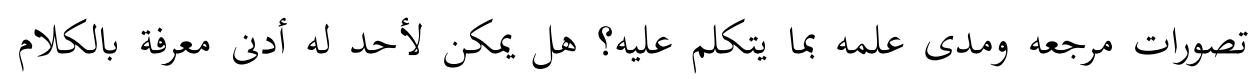

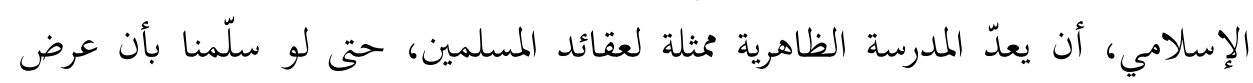

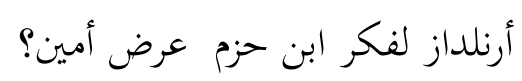

والعجب كله من تصديق المحاضر لتصديق ثيودور الخوري رأي الإمبراطور في تعليل

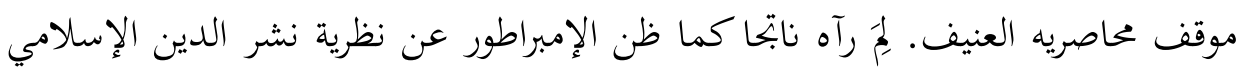

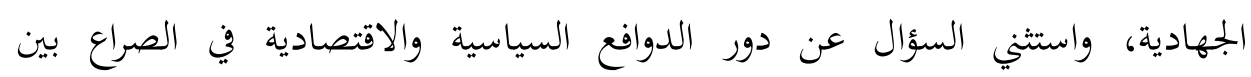

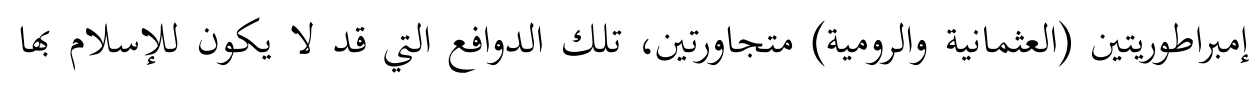

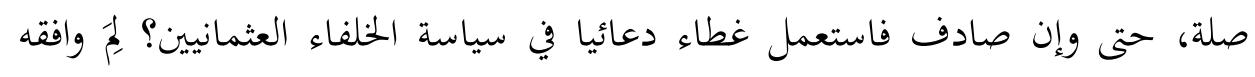

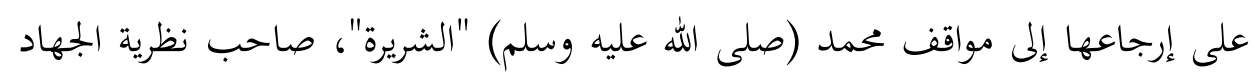

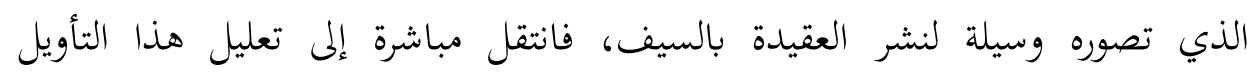

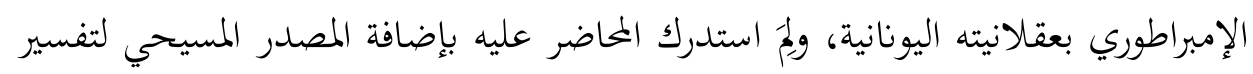

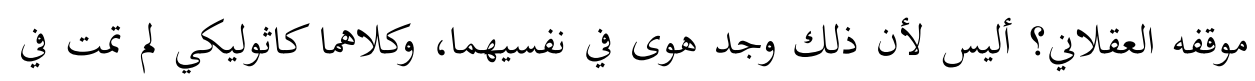

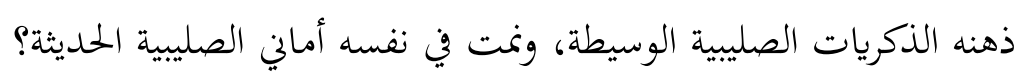

هبْ أنّا سلّمنا بأن كل دعاوى ثيودور الخوري ومصدريه صحيحة، فهل كانت

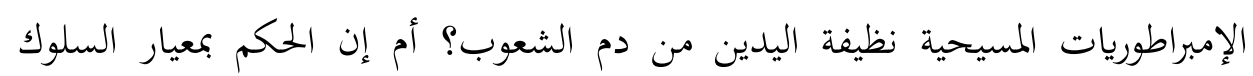

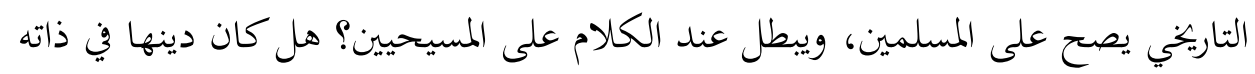

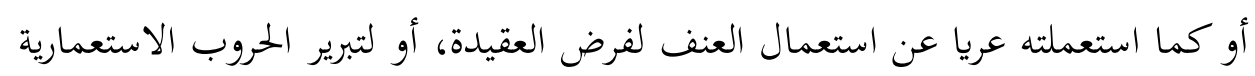

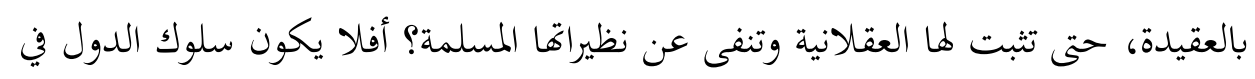

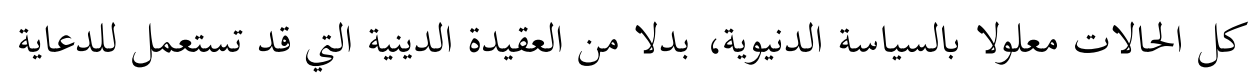

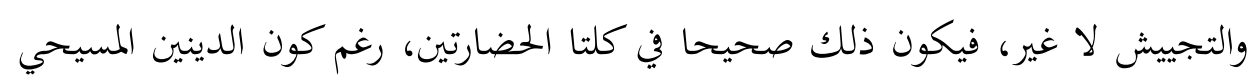

$$
\text { والإسلامي من ذلك السلوك براء؟ }
$$

وفي الجملة هل يصح لمحاضر يزعم أنه يحاضر بصفته أستاذاً ومفكراً، أن يكون هذا المها

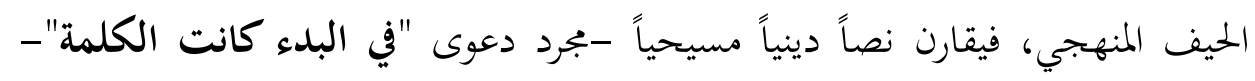


حول العقلانية، بواقعات مستمدة من التاريخ السياسي الإسلامي، حول ما يعتبر منافياً

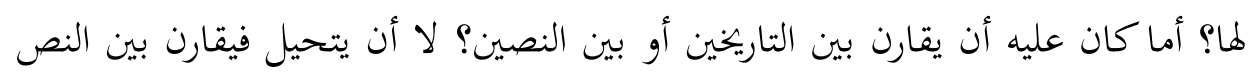

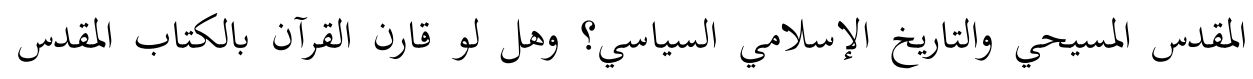

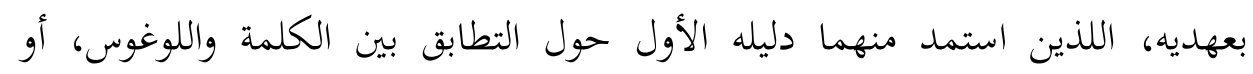

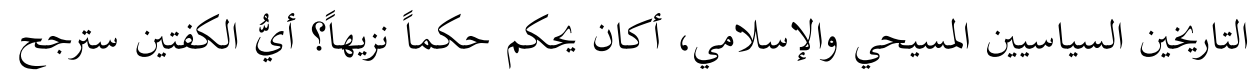
في بجال العقلانية بمعيار العنف والقتل بلا حد؟ الإني المين

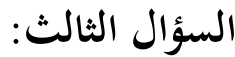

ولنأت إلى السؤال الجامع. فنص المحاضرة لم يعان من هذه الهنات الشكلية بسبب

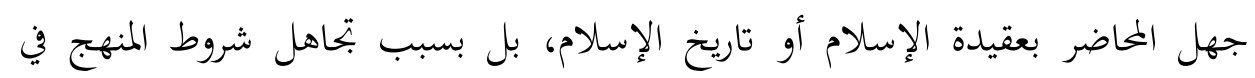

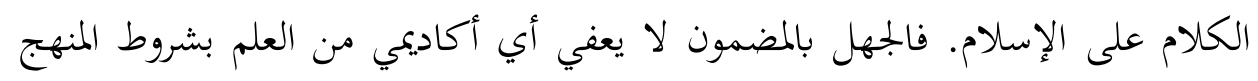

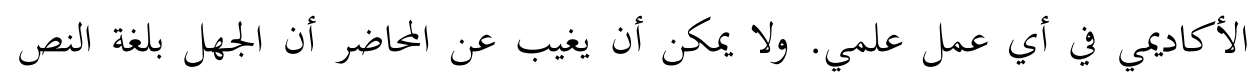

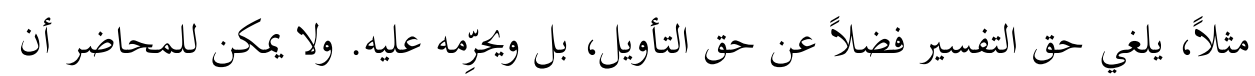

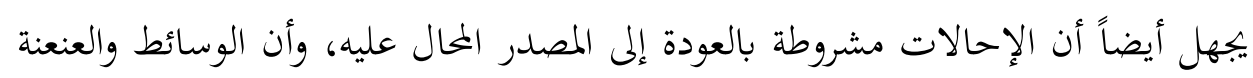

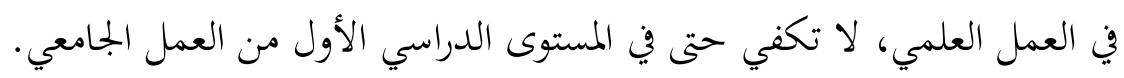

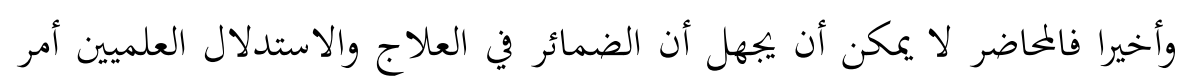

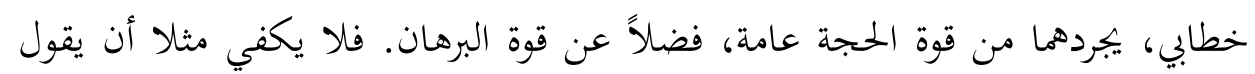

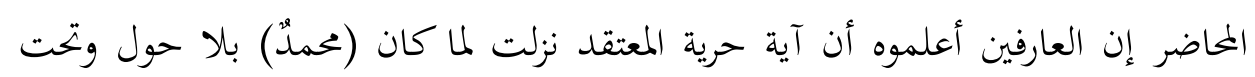

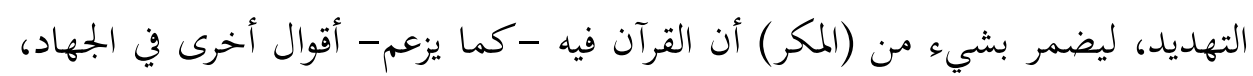

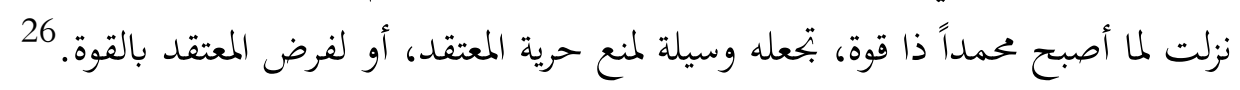
فهذا الكلام يضمر بشيء من المكر أن هذه "التحديدات" تتضمن فرض العقيدة

26 "الكن الإمبراطور كان كذلك يعلم دون شـك أنه قد نزلت في القرآن لاحقا تحديدات حول الحرب المقدسة (الجهاد)." الإنر 
بالقوة، لتعلل بها موقفه من الرسول محمد

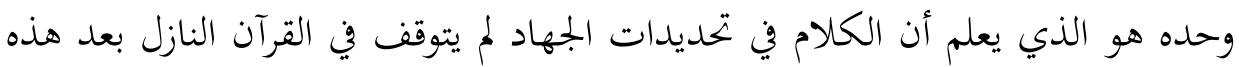
الآية. لكن العارفين يعلمون أن هذه التحديدات كانت لحصره في الدفاع عن حرية

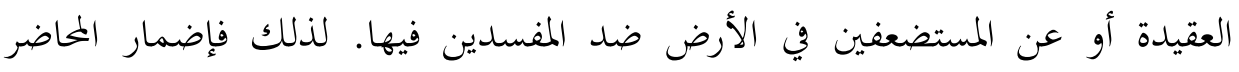

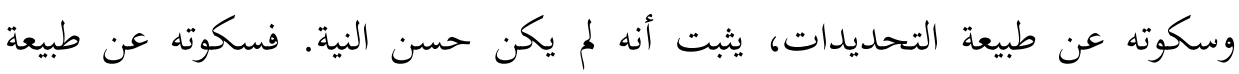

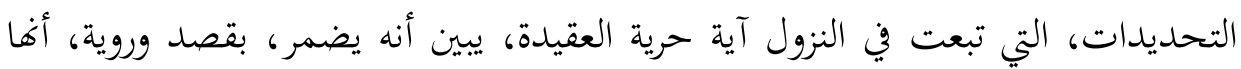
من طبيعة مقابلة للآية التي تقول بحرية العقيدة، ومن تمح فهي من طبيعة تمنع حريتها

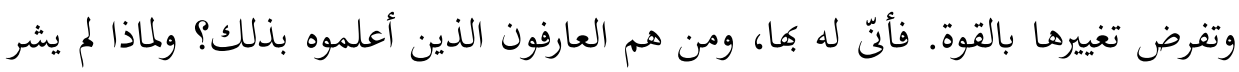
إلى أي منها أو أي منهم؟ تعنما بالقوة

كل هذه القرائن المستمدة، مما يبدو أخطاء شكلية، تبين أها لم تكن أخطاء عن

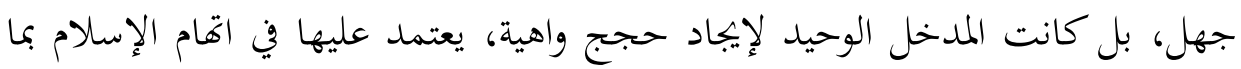

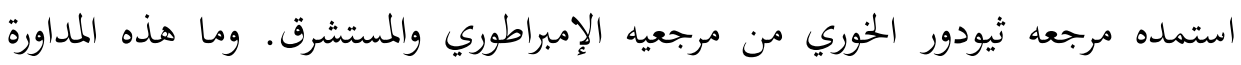

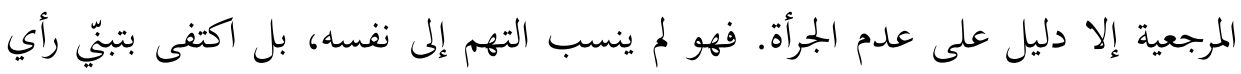

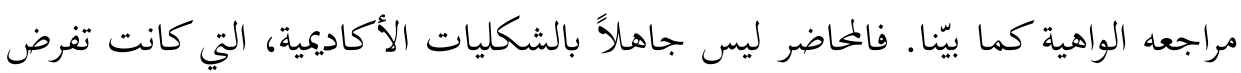

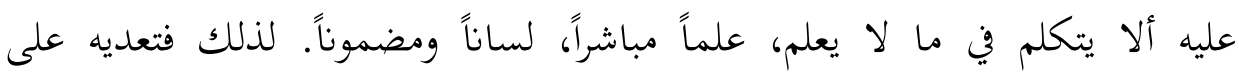
الشكليات دليل على أنه قصد الكلام في ما يجهل، حتى يقول ما يؤيد به حربه المقدسة على الإسالام.

فليس جديداً أن يرى المحاضرُ الإسلامَ خطراً يهدد أوروبا. وليس سراً أن يسعى المحاضر إلى التقرب من الإمبراطور الحالي (في واشنطن)، بالإحالة إلى الإمبراطور السابق.

\section{المسألة الثالثة: تعليقات على أخطاء نتجت عن الخلل المضمولي}

لاحظنا مما سبق أن الأخطاء الشكلية التي وقع فيها المحاضر كانت المدخل الوحيد لمن يريد أن يختلق صورة مشوّهة للإسلام. لكن تجميل المسيحية، الذي سعى لئي إليه

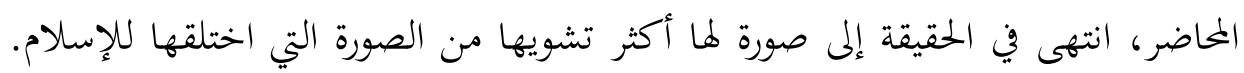


ذلك أن التجميل المستهدف أصبح تشويها للعقل والدين معاً، فضلا عن تشويه العلاقة

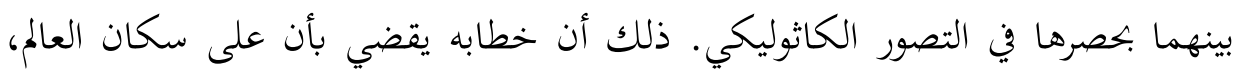

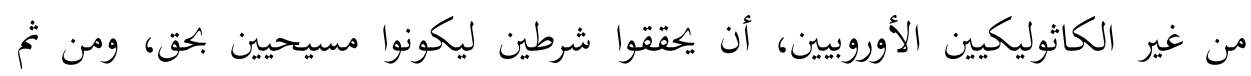

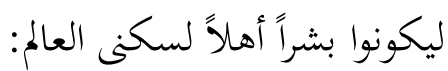
1. عليهم أن يتبعوا الكاثوليكية الأوروبية، التي هي عنده ليست حالئ حدثاً حاسماً في

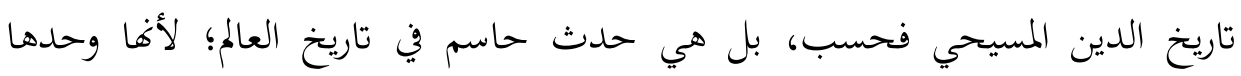

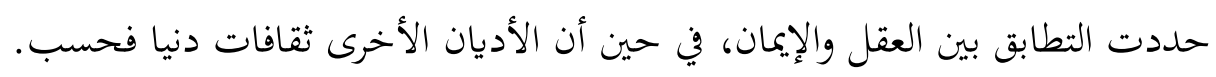

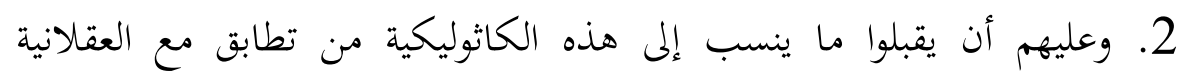

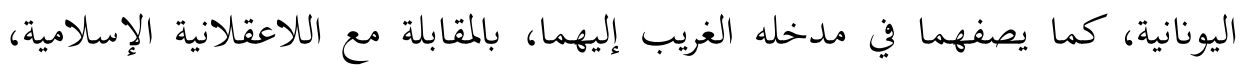

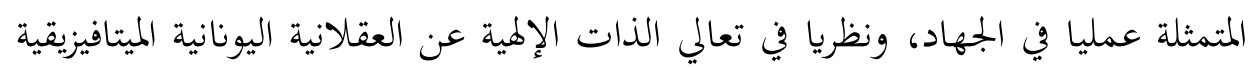
قياساً للعقل الإلهي بالعقل الإنساني.

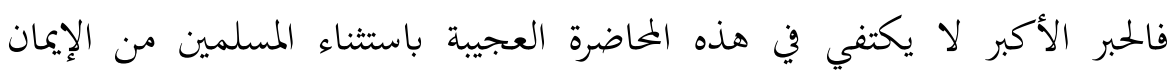

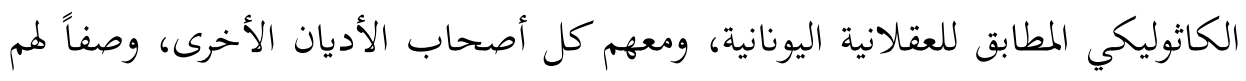

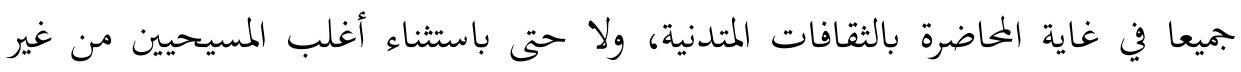

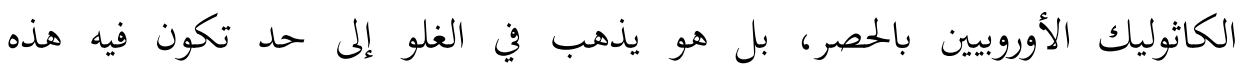

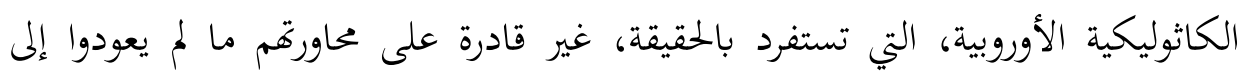

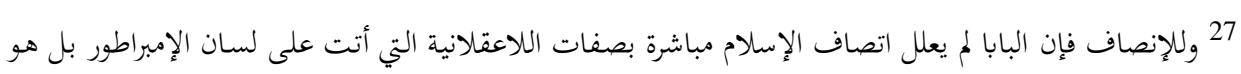

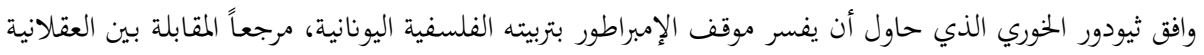

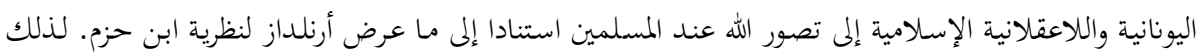

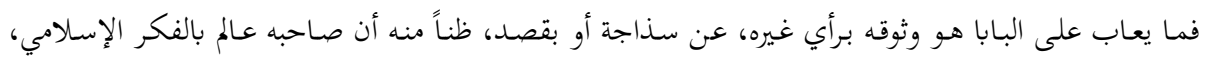

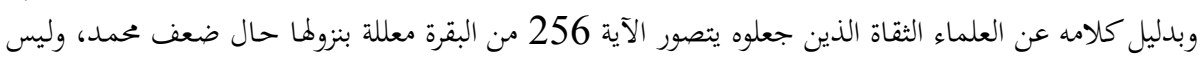

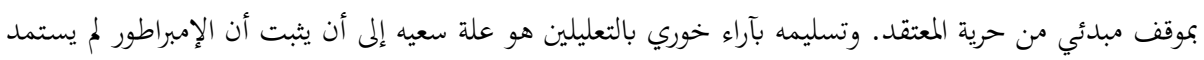

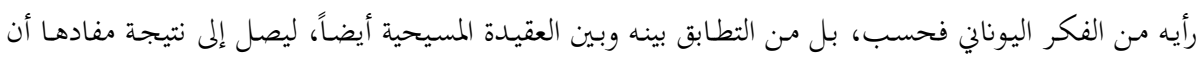

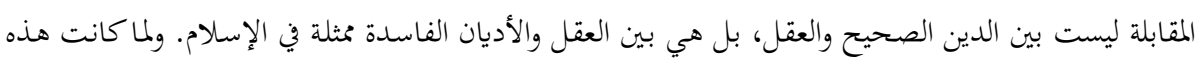

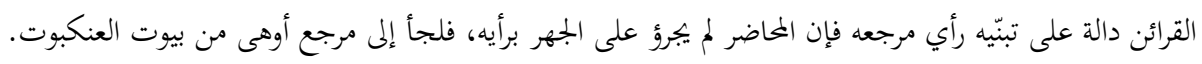


رؤاها الدينية والفلسفية، بفضل إعادة تدريس اللاهوت الكاثوليكي في الجامعات الأوروبية. فالمحاضر لا يزال يحلم بالمركزية الكاثوليكية في أوروبا، والمركزية الأوروبية في العالم.

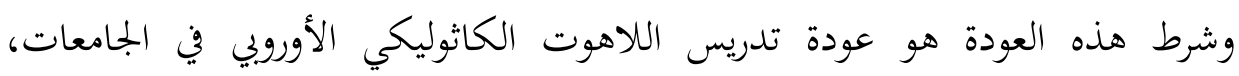

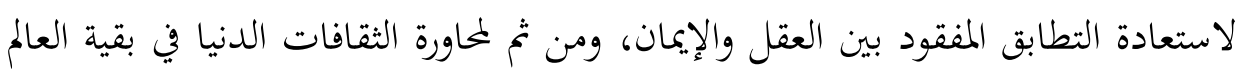
من أجل هدايتهم.

وتبين قراءة المحاضرة قراءة دقيقة أن البابا قد صنف البشر بمعيار أدياهم بين حدّيْن:

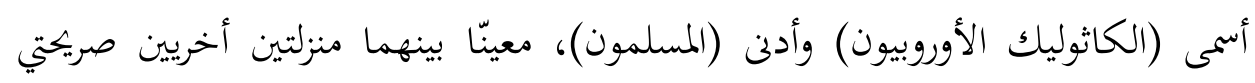
الذكر بالوصف، وإن لم تكوناه بالتسمية:

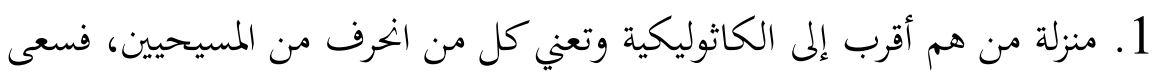

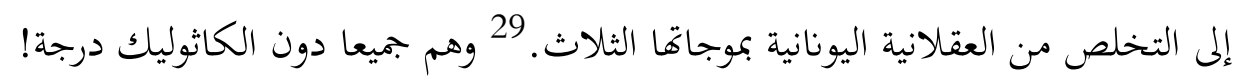
2. ومنزلة من هم أقرب إلى المسلمين من باقي البشرية ذوي الثقافات الدنيا، الذهاكا، الذين ستحاورهم الكنيسة. وهم جميعا فوق المسلمين درجة! بهذا التصنيف وحده يمكن للبابا عملاً بقاعدة "وبضدها تتميّز الأشياء"، أن يبرر انطلاقه 30 من تأويل ثيودور الخوري لموقف الإمبراطور الوارد في نصه، ليقابل بين عقلانية

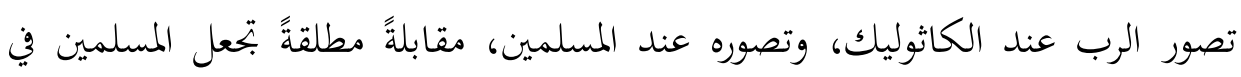

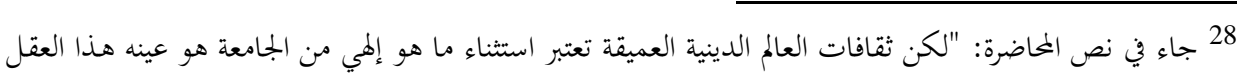

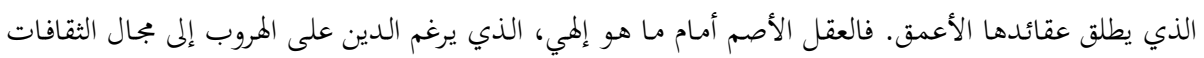

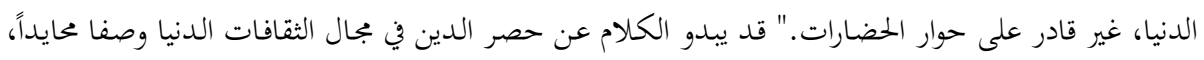

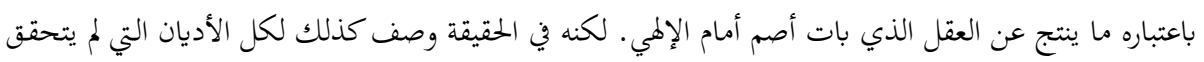

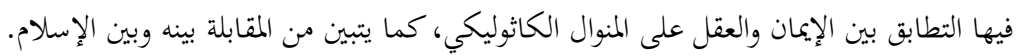

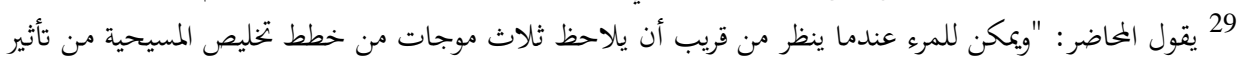

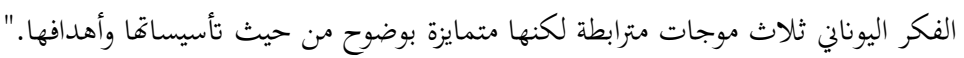

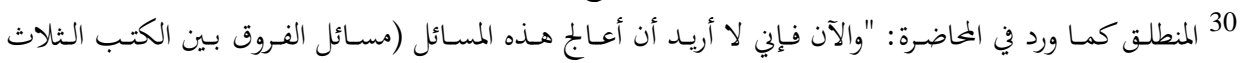

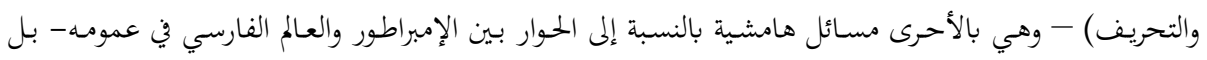

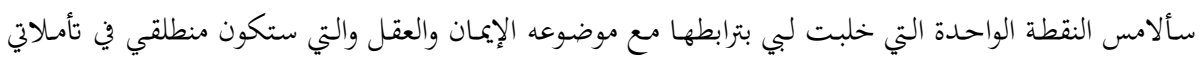

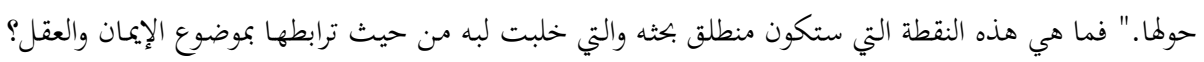

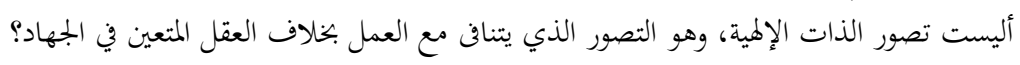


الدرك الأسفل، والكاثوليكيين الأوروبيين الذين ينطق البابا باسمهم في عليين. والجديد في

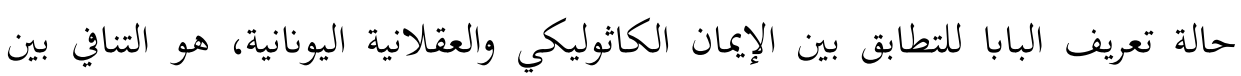

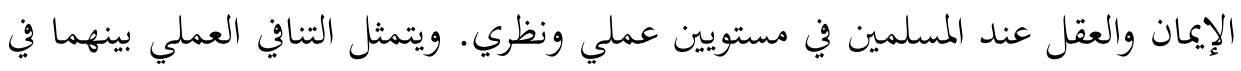
فرض العقيدة بالسيف، ذلك الفرض الذي يطابق بينه وبين الجهاد (نص الإمبراطور).

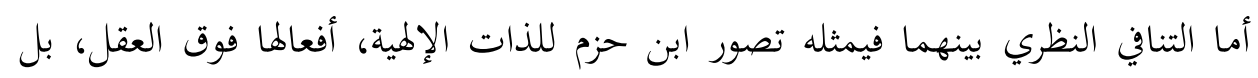
وقابلة لأن تكون منافية له. 32

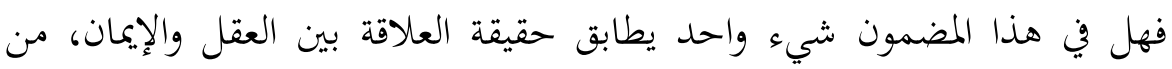

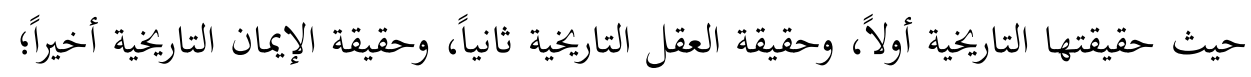

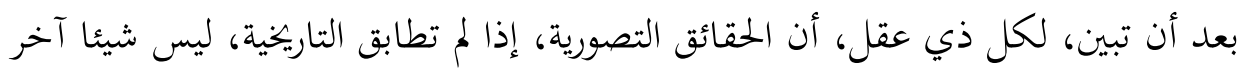

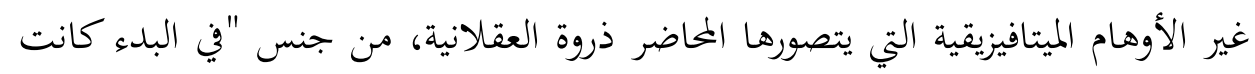

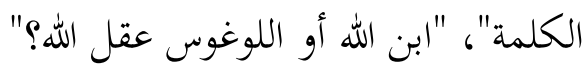

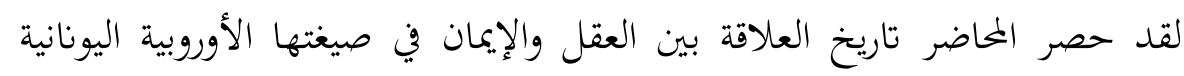

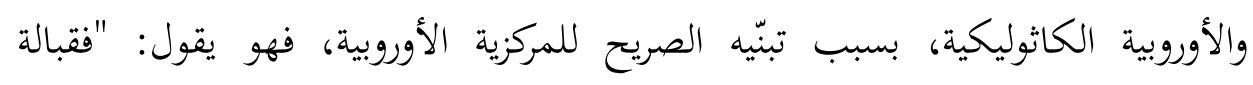

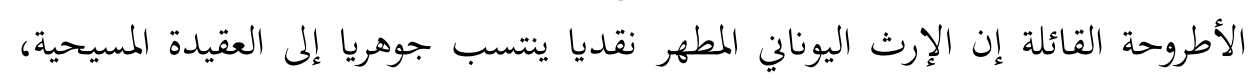

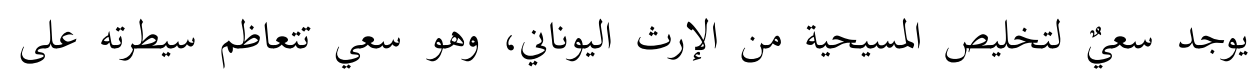

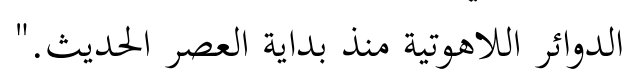

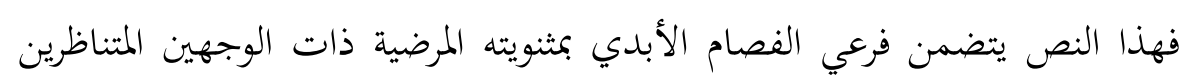

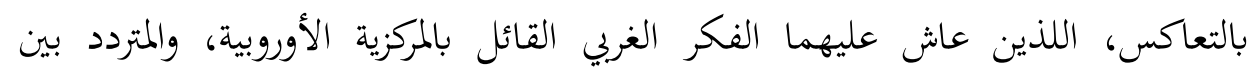

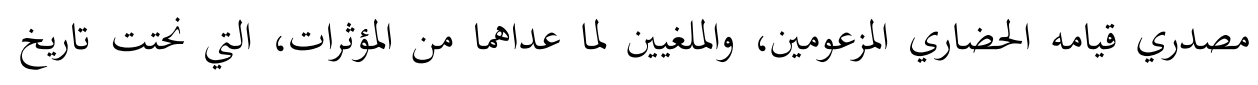

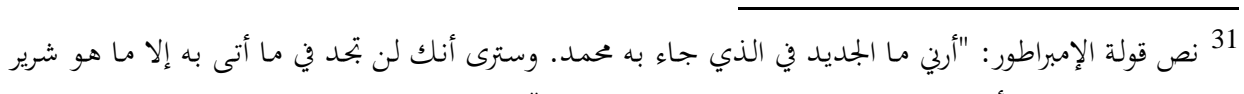

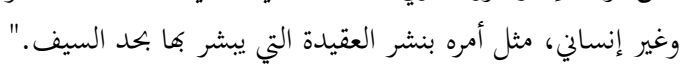

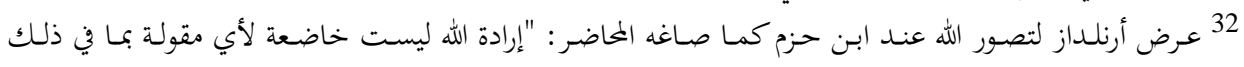

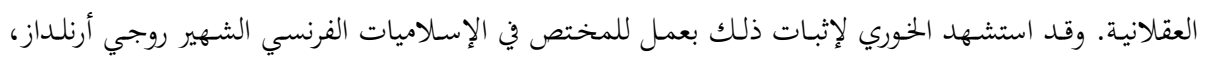

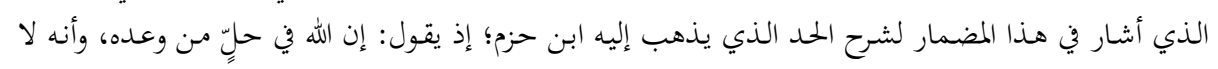

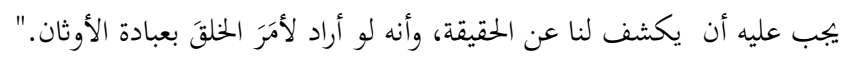


أوروبا، ومن أهها الإسلام. والمصدران المزعومان دائماً هما المصدر اليوناني والمصدر

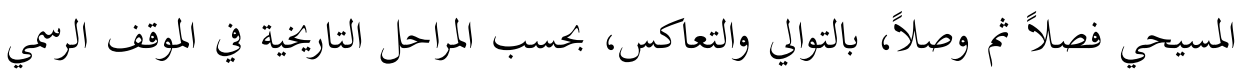

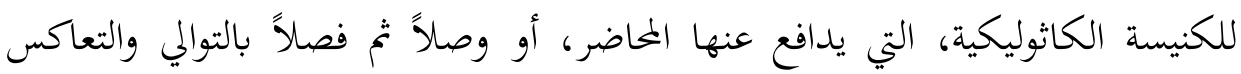

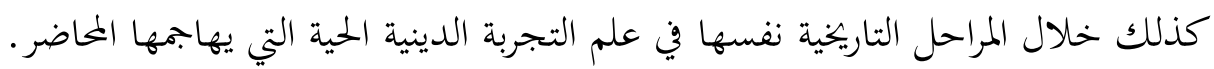

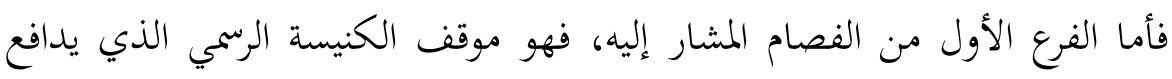

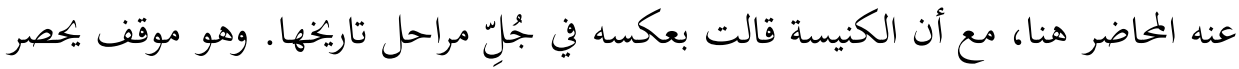

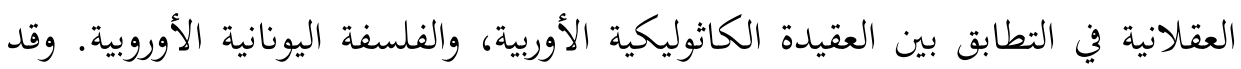

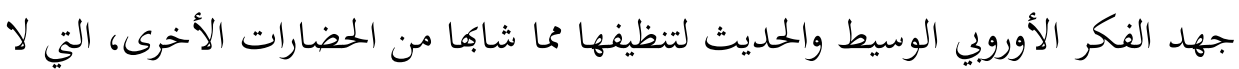

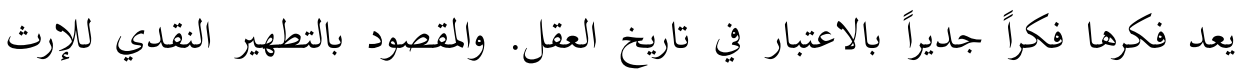

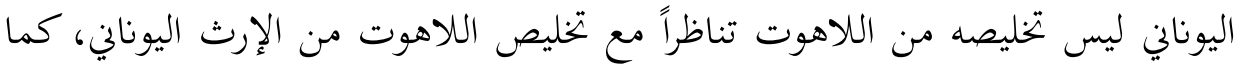

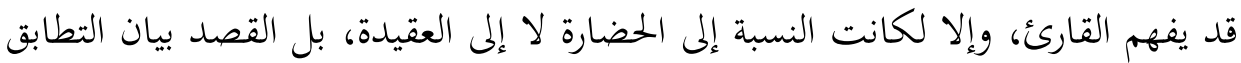

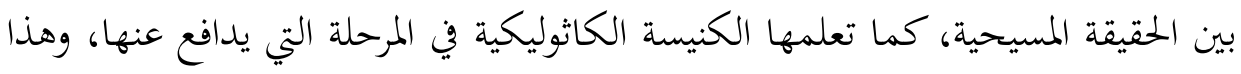
الفكر عندما يخلص من المواريث الأخرى غير الأوروبية.

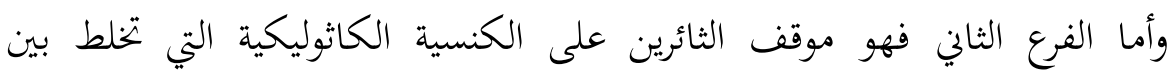

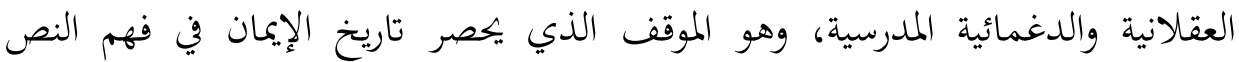

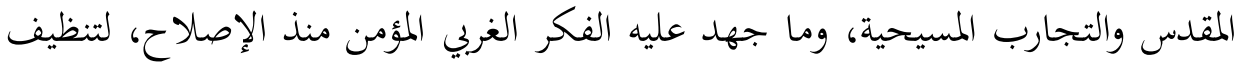

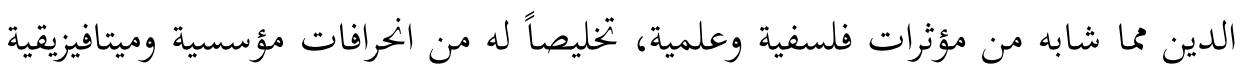

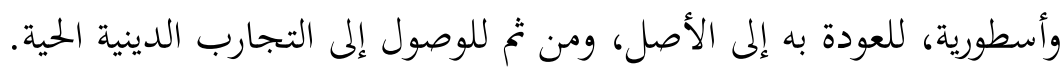

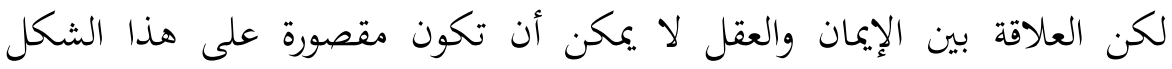

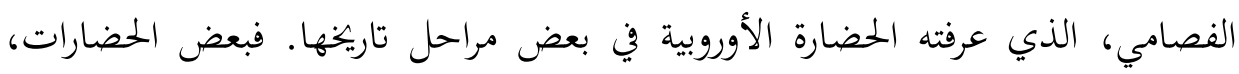

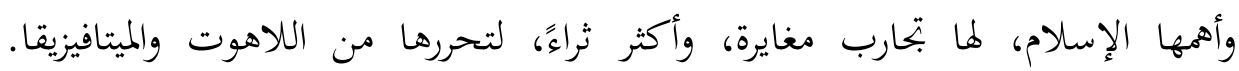

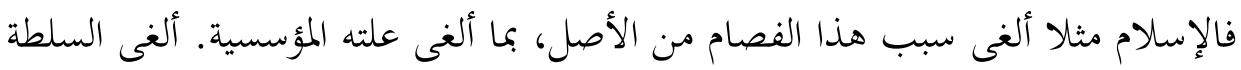

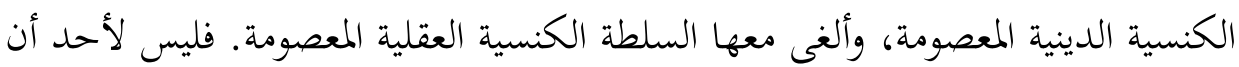

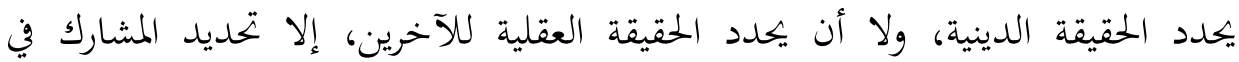


الاجتهاد من حيث هو تواص بالحق، وممارسة فعلية لمعاني التجربة الدينية نفسها، كما تحددت في المفطور، سواء كان من المسطور أو من المنشور.

ومن تم فلا معنى للتنظيف النقدي الذي يتكلم عليه المحاضر، إلا ما تحقق منه في التجارب الروحية الإنسانية المختلفة، التي لا يخلو منها دين، وليست حكراً على العقيدة الكاثوليكية الأوروبية، كما يزعم المحاضر . فكل الاجتهادات البشرية في التجربتين العقلية

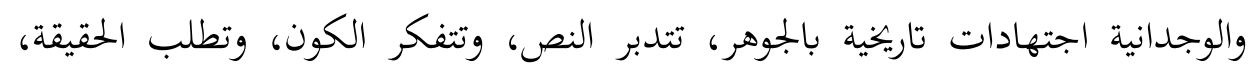

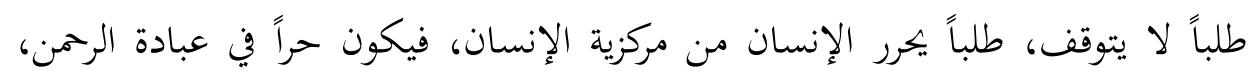
وذلك هو مفهوم الفطرة كما حدده القرآن.

كيف يمكن للعقل أن يكون لا تاريخياً، فتكون صورته اليونانية، التي هي بدايٌّ غُفلةٌ، مغنيةً عن صورته التي هي غاية، بالقياس إلى تلك البداية، وهي غاية تحققت عند من تبعهم من العالمين؟

كيف يمكن أن تكون التجربةُ اليونانية الوجودية والمعرفية والقيمية غايةً التجارب الإنسانية، التي لا يمكن أن يتجاوزها التاريخ البشري رغم كوفا بداية ساذجة فحسب؟ كيف يمكن أن يُعَدّ ما تبع ذلك صيغة المطابقة بين هذه الصورة من العقل اليوناني

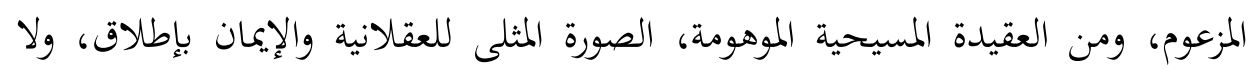

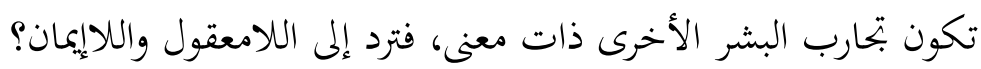
هل يعني البابا أن الناس لن يصبحوا بشراً إلاّ إذا تأوننوا (أصبحوا يونانا) وتكثلكوا! وإلا فإفم معدودون من ذوي الثقافات الدنيا؟ هل يمكن أن يقول بذلك من لم يكن حبيس المركزية الكاثوليكية أوروبياً والأوروبية

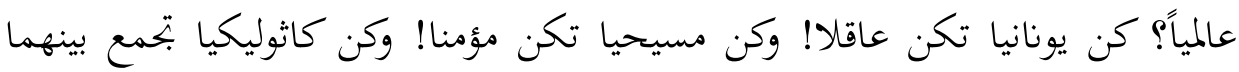

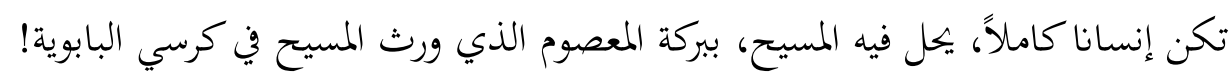
ولنضرب مثالا يبين للمحاضر ولمراجعه مدى الجهل بالتجارب الأخرى التي تصوروها 
من اللامعقول. فمضمون التجربة الإسلامية في علاقتها بالعقلانية، إذا قيست بمعيار

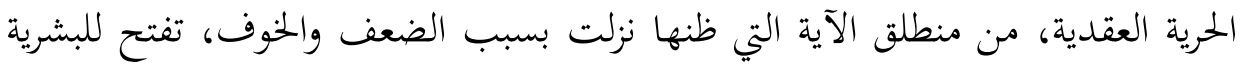

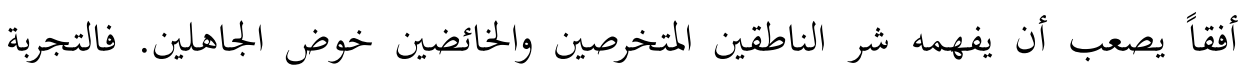

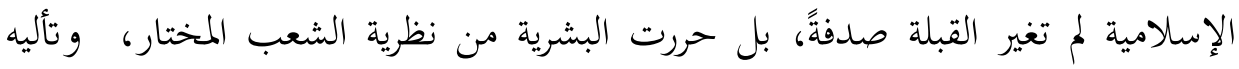

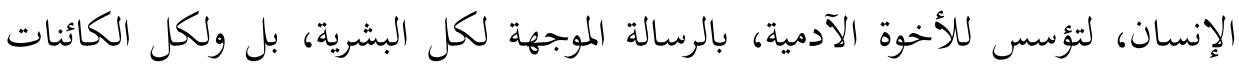

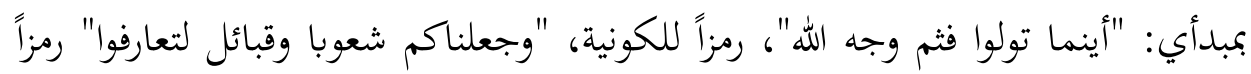

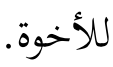

لذلك فسعي المحاضر للحد من آية حرية المعتقد، بسبب نزولها والظرف الذي رافق

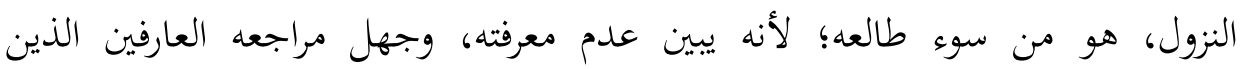

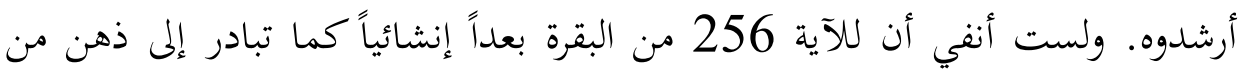

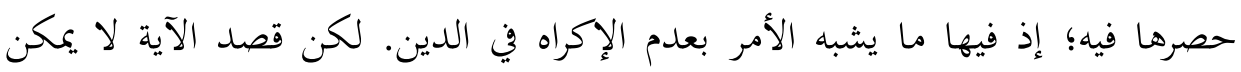

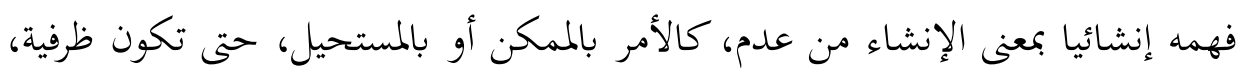

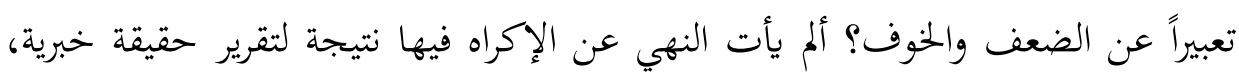

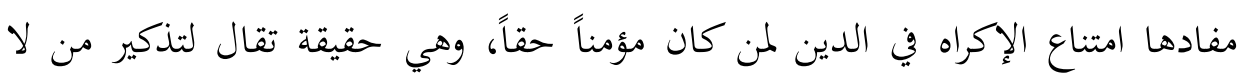

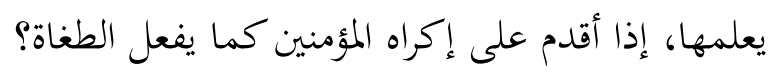

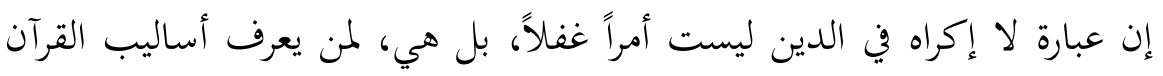

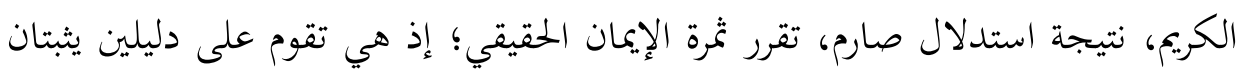
استحالة الإكراه في الدين، ولا تقتصر على النهي عن الإكراه فيه.

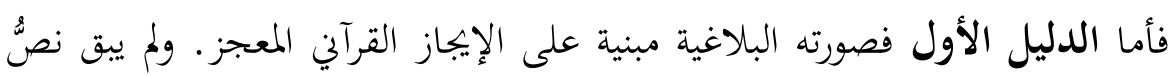

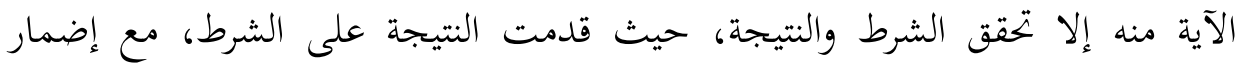

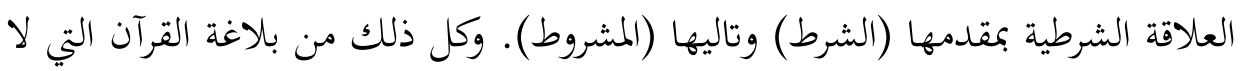

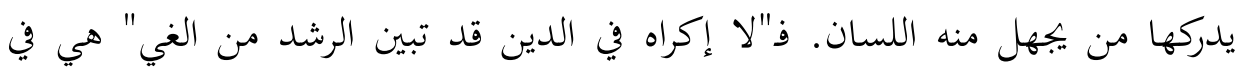

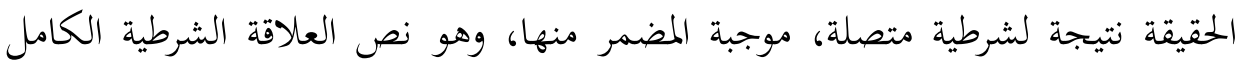

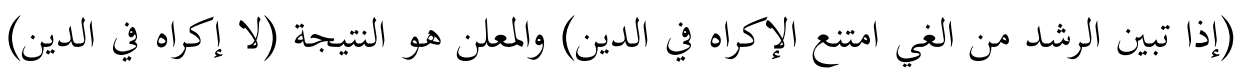


وتحقق الشرط (قد تبين الرشد من الغي). وكل ذلك في القسم الأول من الآية، القسم الذي يمكن تحليل صورته على النحو التالي:

العلاقة الشرطية (مضمرة): إذا تبين الرشد من الغي (مقدم) امتنع الإكراه في الدين

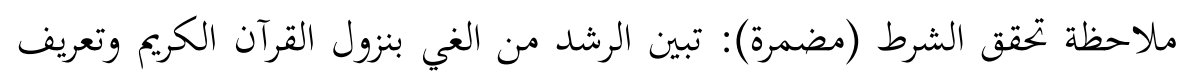
الذات الإلهية في آية الكرسي المتقدمة على هذه الآية. النتيجة: لا إكراه في الدين ومعناه امتنع الإكراه في الدين.

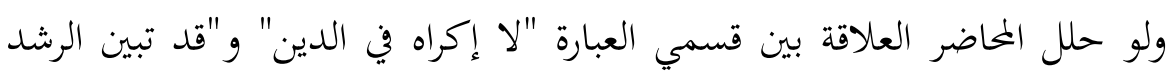

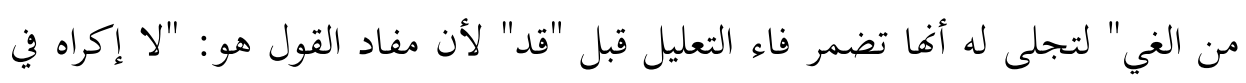

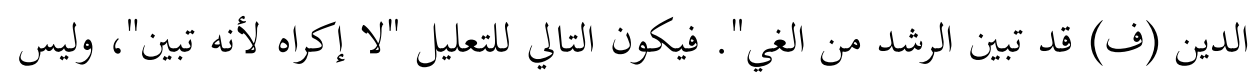

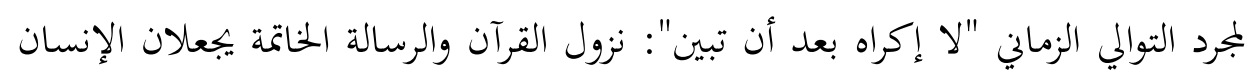

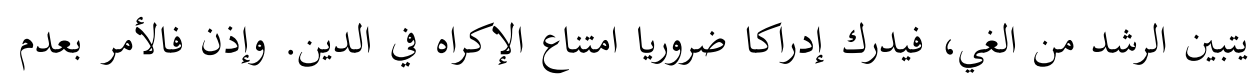

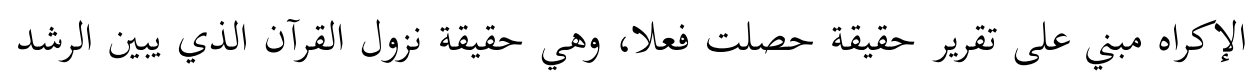

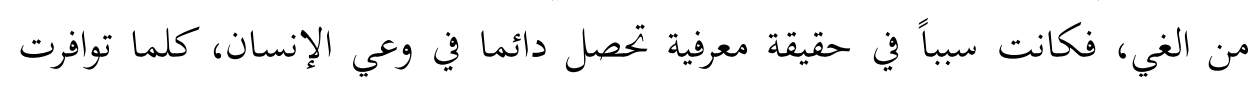

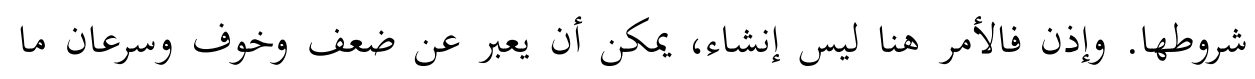

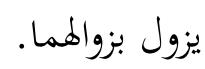

وبذلك نفهم لمُ يُ يتكلم القرآن الكريم دائما عن التعدد الديني بوصفه سنة من سنن

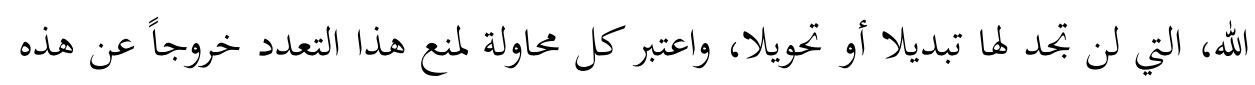

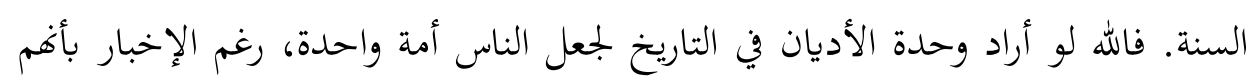

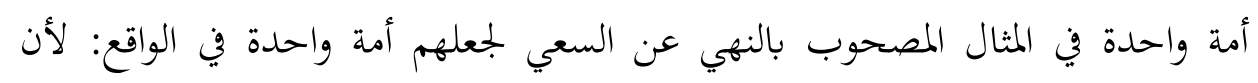

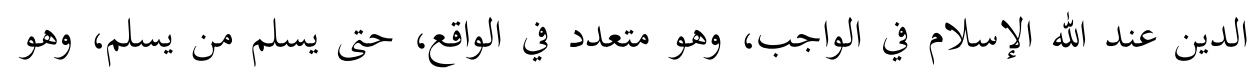

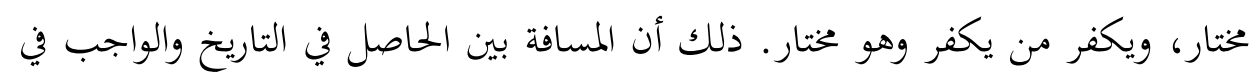

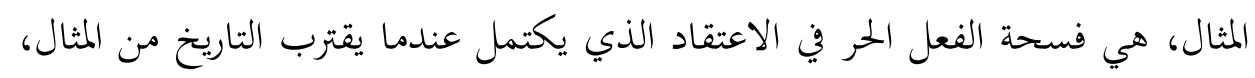


فيحصل الإدراك الجازم بامتناع الإكراه في الدين: من دون ذلك لن يكون تبين الرشد من الغي ثمرة للاجتهاد، وحماية حرية المعتقد ثمرة للجهاد. لإدراه

لذلك فقد فرض القرآن على المسلمين حماية حرية المعتقد في كل الأديان بالجهاد،

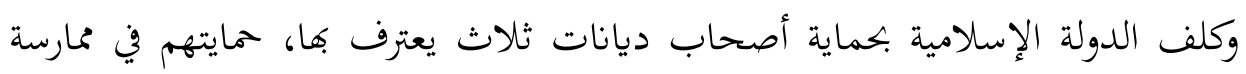

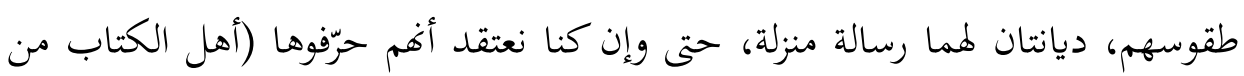

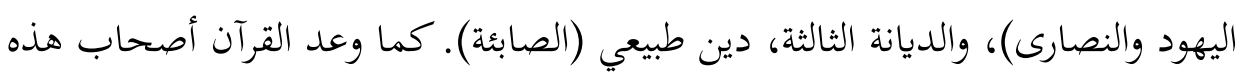

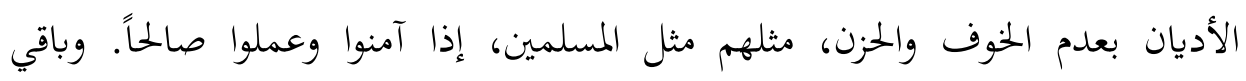

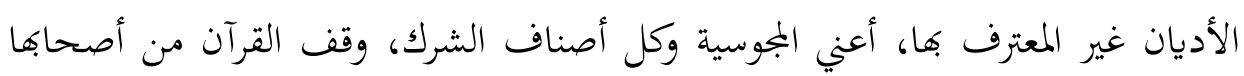

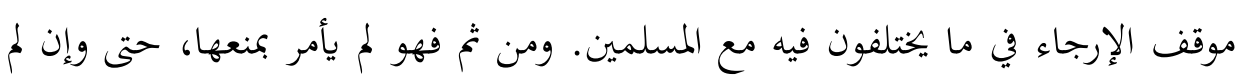

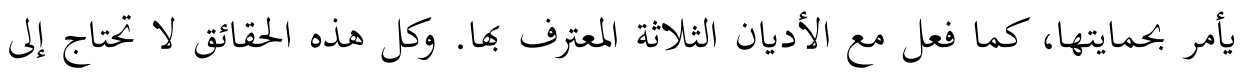

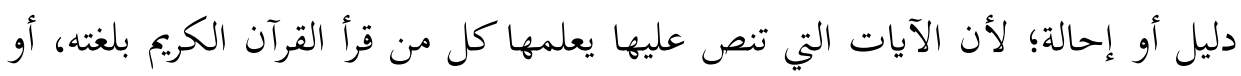

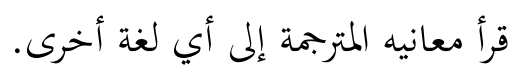

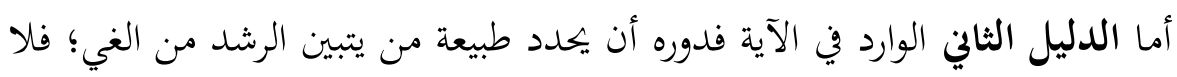

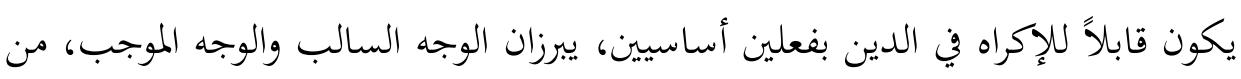

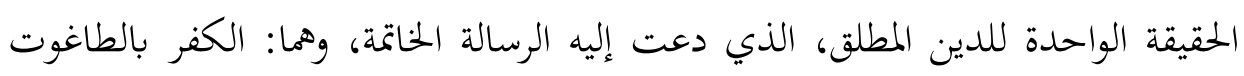

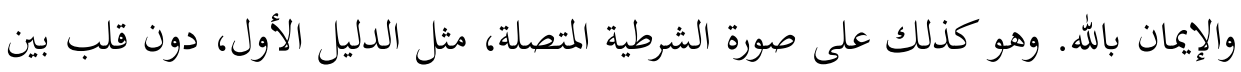

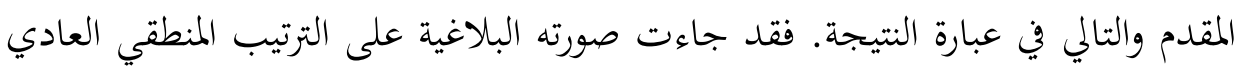
بين النتيجة وشرطها، رغم ازدواج مقدمته بسبب ازدواج نتيجته.

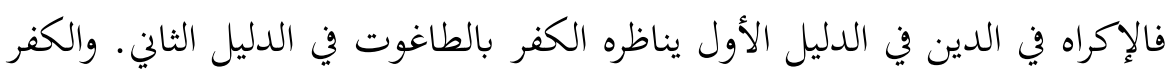

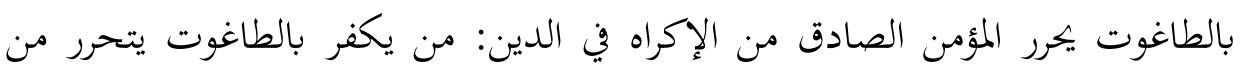

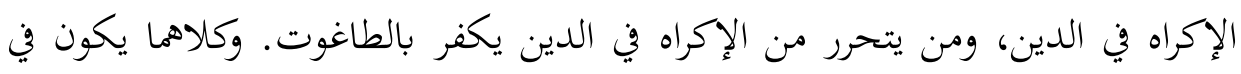

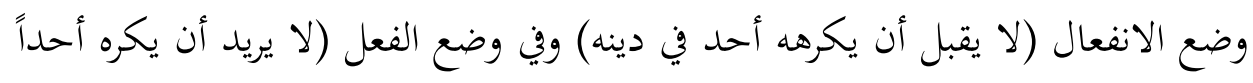

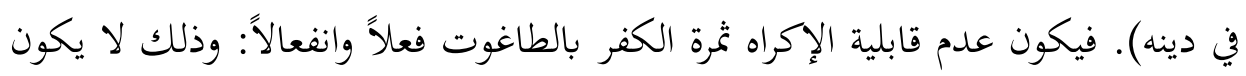

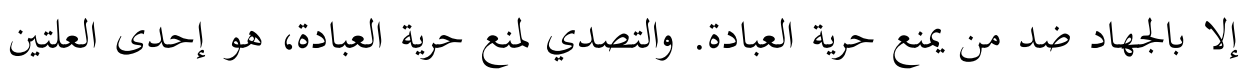


اللتين تشرعان الجهاد في الإسلام حصراً فيهما، لكوغما فرعي الفساد في الأرض الروحي

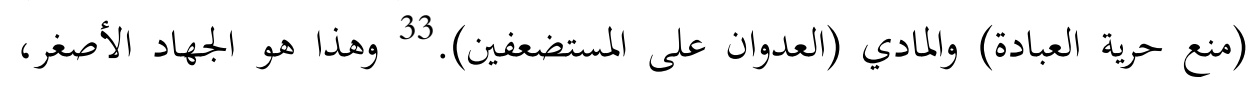

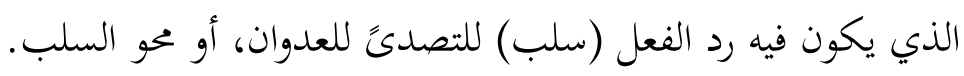

وتبين الرشد من الغي في الدليل الأول يناظره الإيمان بالله في الدليل الثاني. وكلاهما

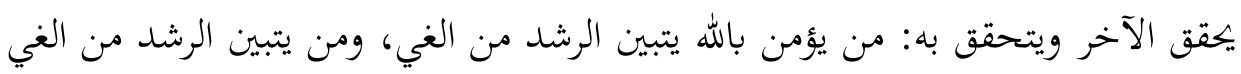

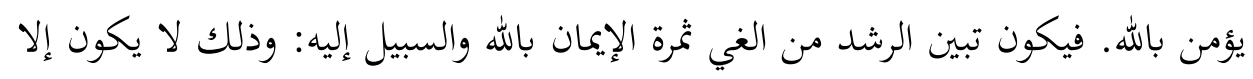

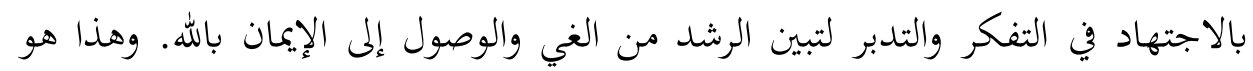

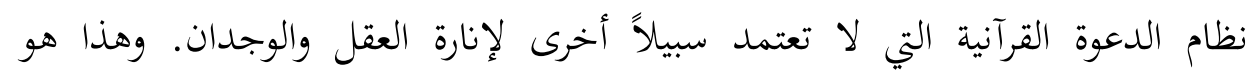

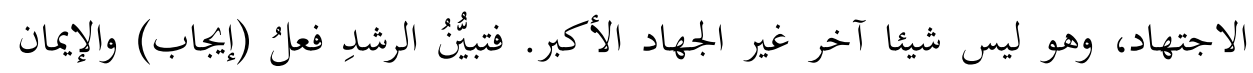

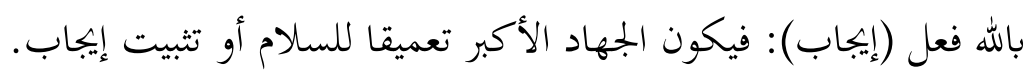

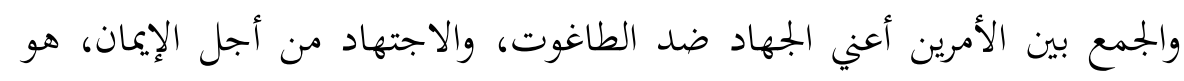

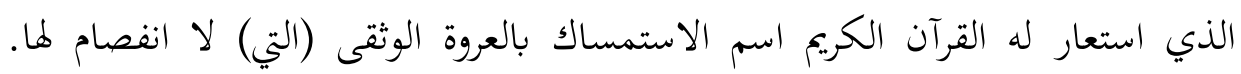

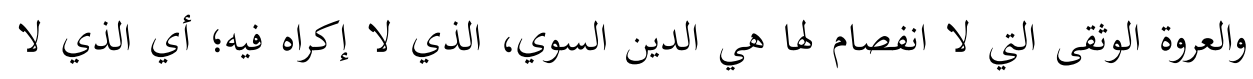

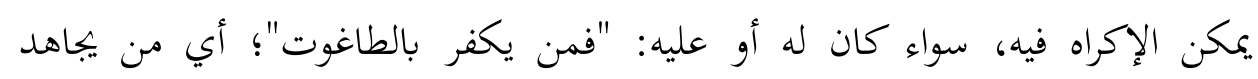

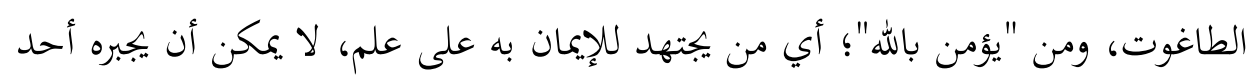

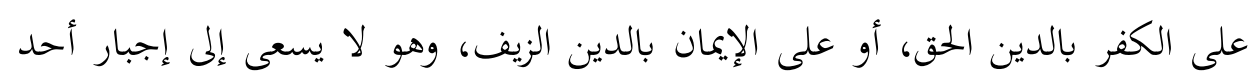
عليهما، وإن كان من واجبه أن يسعى بالتي هي أحسن لتبليغ الدعوة إليهما. وكان يمكن لو كان المقام يسمح بتجاوز تحليل النصوص، أن نقارن تاريخاً بتاريخ؛

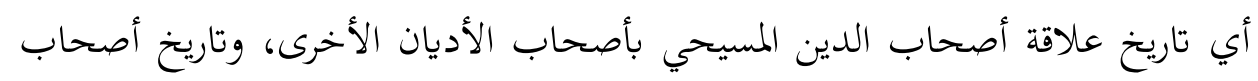

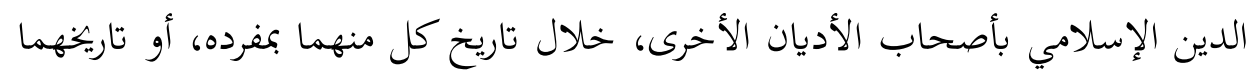

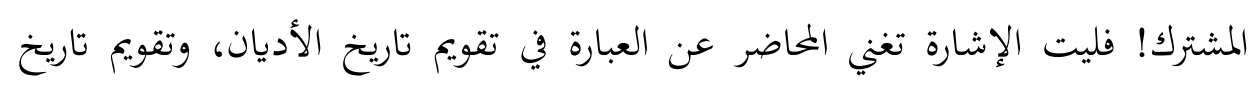

33 التصدي لمن يمنع حرية العبادة هو العلة الأولى للجهاد. والعلة الثانية هي التصدي لمن يعتدي على المستضعفين وعلى حقوقهم. 
الوجدان، وتقويم تاريخ العمران، لندرك أيهما أقرب لحقيقة الإنسان، حيث يتطابق

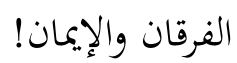

\section{الخاتمة}

نختم القول في التعليق على محاضرة بابا الفاتيكان بالسؤال عن ثمرة تخليص المسيحية

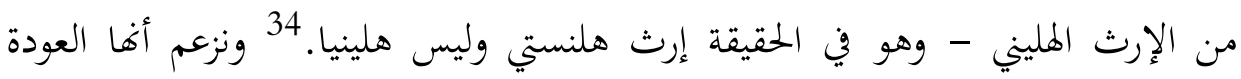

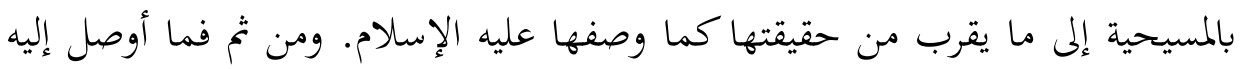

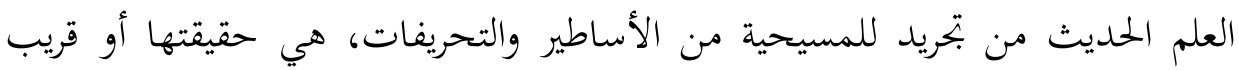

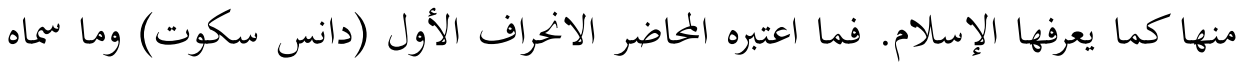
موجات ثلاث متتالية من تخليص المسيحية من العقلانية (الإصلاح واللاهوت الليبرالي

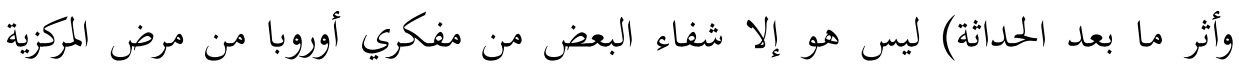

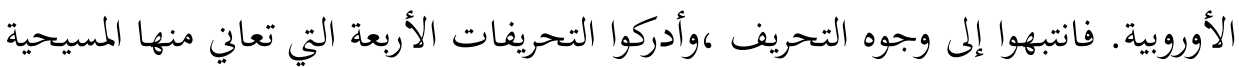

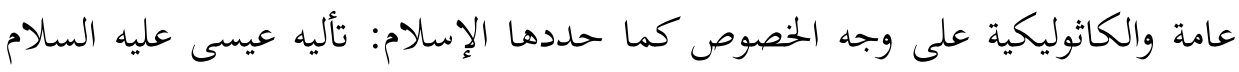

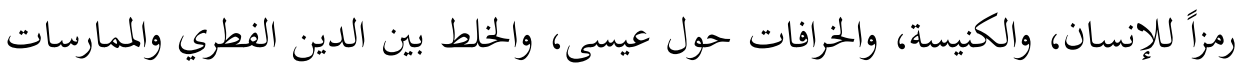

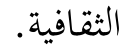

فما ظنه المحاضر انحرافا في اللاهوت المسيحي خلال العصور الوسطى المتأخرة، أعني

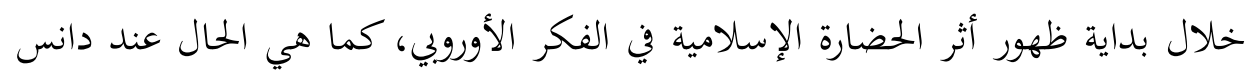

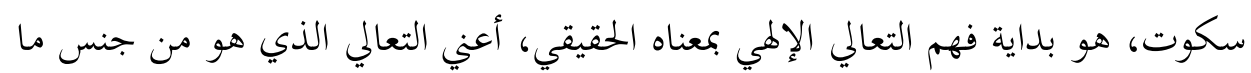

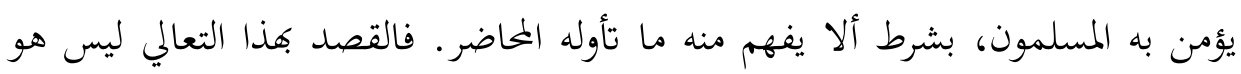

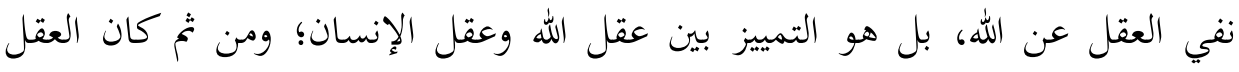
الإنساني عقلا اجتهاديا، لا عقلا ميتافزيقيا. وذلك هو شرط تعميق الإنيان الإمان وتقديم العلم:

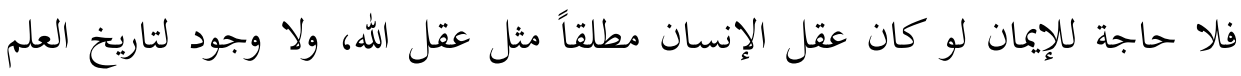

34 المرحلة الهلنستية هي مرحلة الفكر اليوناني بعد الغزو المقدوني للشرق في هاية القرن الرابع قبل الميلاد والمرحلة الهلينية

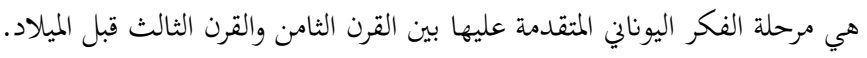


والمعرفة لو كنا نعلم بإطلاق، ولسنا نجتهد قدر المستطاع. ثم إن التمييز بين عقل الله وعقل الإنسان هو الشرط الضروري والكافي للتخلص من

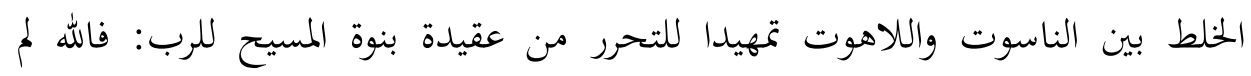

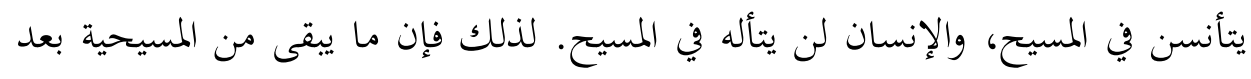

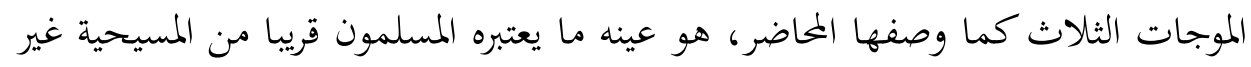

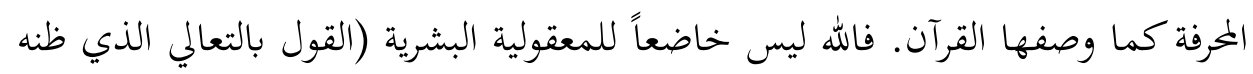

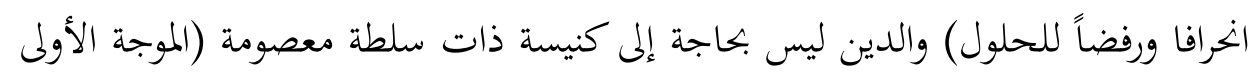

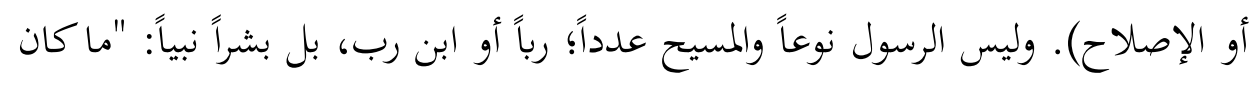

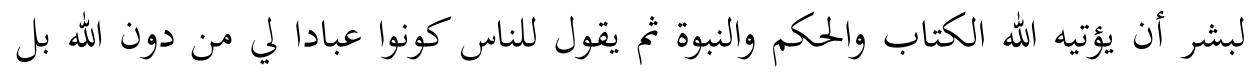

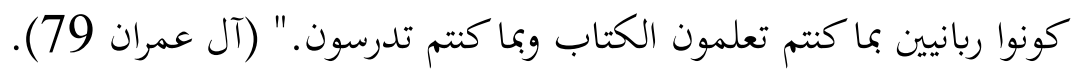

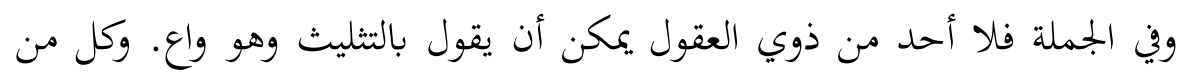

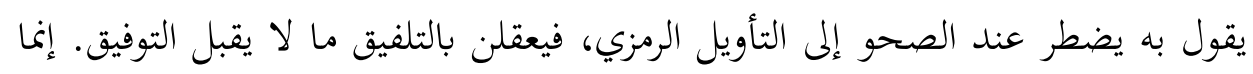

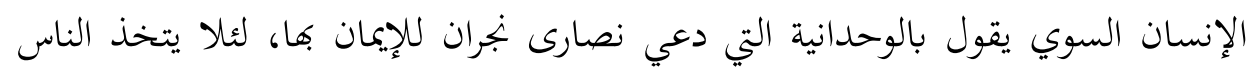

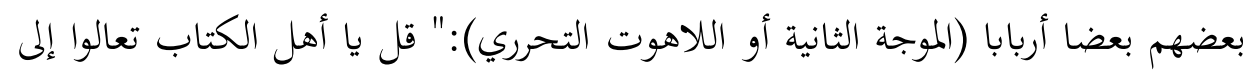

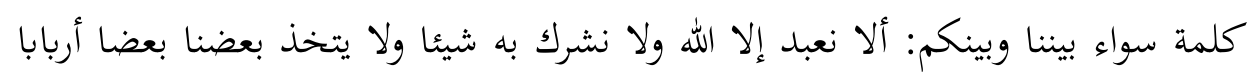

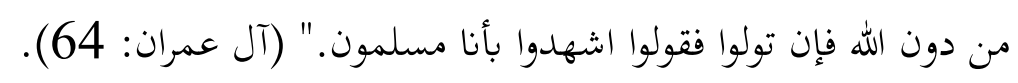

وكل هذه التحريفات التي تخلصت منها المسيحية بفضل هذه الموجات النقدية، هي

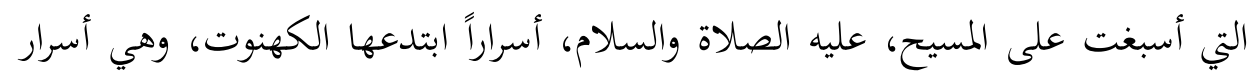

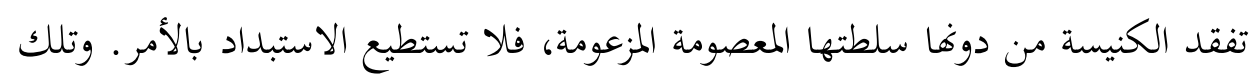

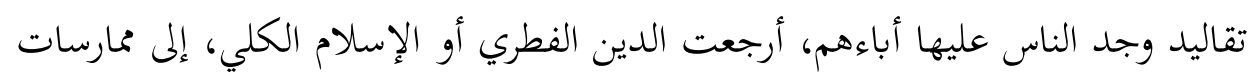
صار الإنسان وثنها الأكبر. (المرحلة الأخيرة من التخليص).

لكن المسلمين لا يسلمون بأن الدين السوي، شكل ثقافي ينبغي التخلص منه.

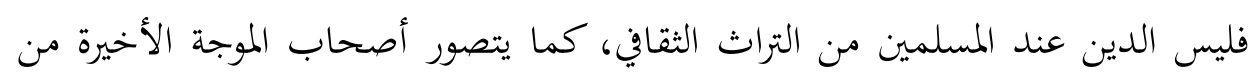


تخليص المسيحية من الفكر اليوناني، في فكر ما بعد الحداثة والثقافوية، كما يشير

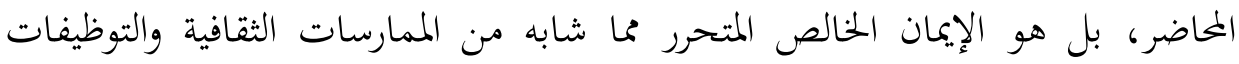

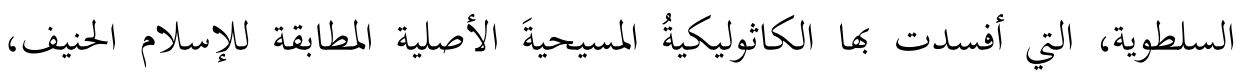
والمتحررة من العقلانية الميتافيزيقية، التي هي بدورها شكل ثنقافي تجاوزه التاريخ. 